THESIS FOR THE DEGREE OF DOCTOR OF PHILOSOPHY (PhD)

\title{
EX VIVO ADHERENT CULTURES FOR OCULAR DISEASE MODELING, CHARACTERISATION AND INFLAMMATION STUDIES
}

Natasha Josifovska, M.Sc.

Supervisor:

Prof. Dr. Goran Petrovski, MD, PhD, Dr. med.habil.

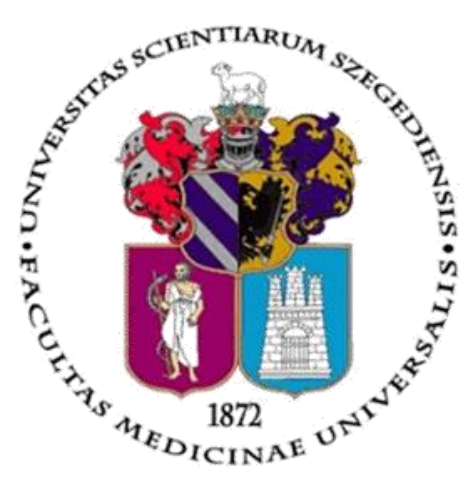

UNIVERSITY OF SZEGED

DOCTORAL SCHOOL OF CLINICAL MEDICINE

DEPARTMENT OF OPHTHALMOLOGY 


\section{Publications}

\section{Publications related to the thesis:}

1. Josifovska $\mathbf{N}^{*}$, Szabó DJ, Nagymihály R, Veréb Z, Facskó A, Eriksen K, Moe MC, Petrovski G. Cultivation and characterization of pterygium as an ex vivo study model for disease and therapy. Cont Lens Anterior Eye. pii: S1367-0484(16)30117-5. doi: 10.1016/j.clae.2017.04.002

2. Andjelic S, Lumi X, Veréb Z, Josifovska N*,Facskó A, Hawlina M, Petrovski G. A simple method for establishing adherent ex vivo explant cultures from human eye pathologies for use in subsequent calcium imaging and inflammatory studies. J Immunol Res. 2014;2014:232659.

IF:2.810

\section{Other publications:}

3. Szabó DJ, Tóth M, Doró Z, Nagymihály R, Josifovska N, Facskó A, Petrovski G. Cell death, clearance and inflammation: molecular crossroads and gene polymorphisms in the pathogenesis of age-related macular degeneration. J Biochem Pharmacol Res. 2014;2 (3), 132-143., 2014

IF: 0.0

4. Szabó DJ, Noer A, Nagymihály R, Josifovska N, Andjelic S, Veréb Z, Facskó A, Moe MC, Petrovski G. Long-Term Cultures of Human Cornea Limbal Explants Form 3D Structures Ex Vivo - Implications for Tissue Engineering and Clinical Applications. PLoS One. 2015;18;10(11):e0143053; doi: 10.1371/journal.pone.0143053.

IF:4.411

5. Szabó DJ, Nagymihály R, Veréb Z, Josifovska N, Noer A, Liskova P, Facskó A, Moe MC, Petrovski G. Ex vivo 3D human corneal stroma model for Schnyder corneal dystrophy - role of autophagy in its pathogenesis and resolution. Histol Histopathol. 2017 Sep 5:11928. doi: 10.14670/HH-11-928 


\section{Table of Contents}

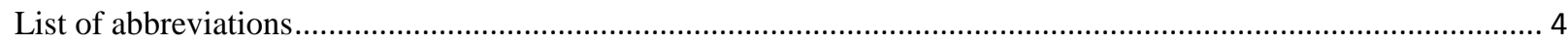

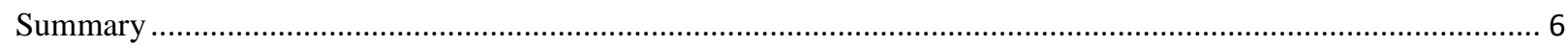

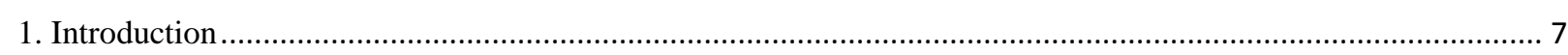

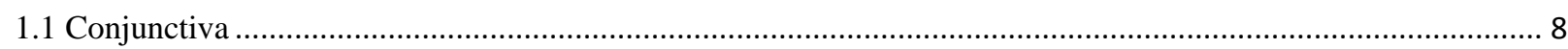

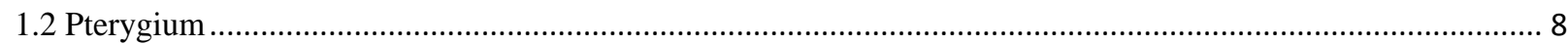

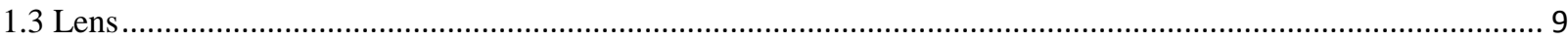

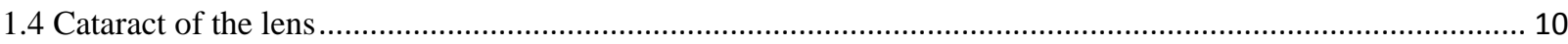

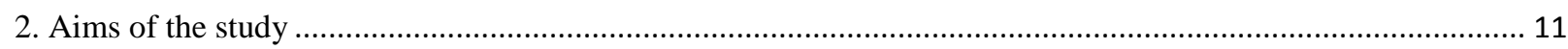

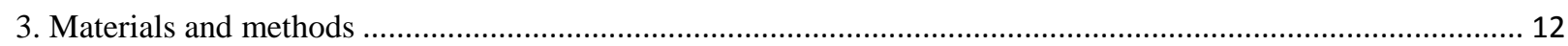

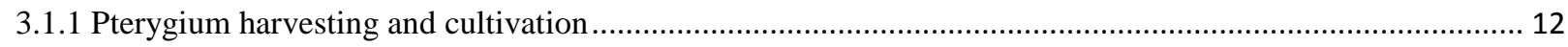

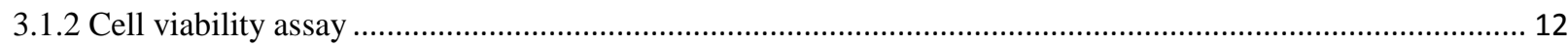

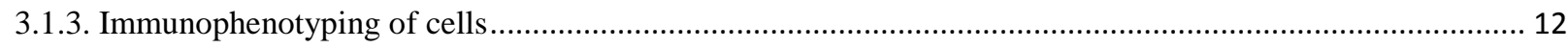

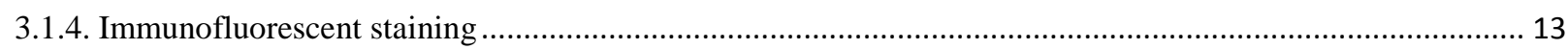

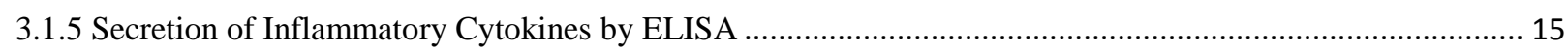

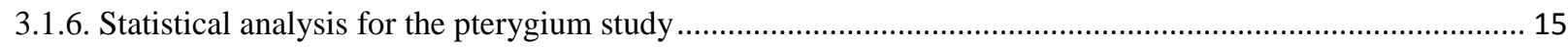

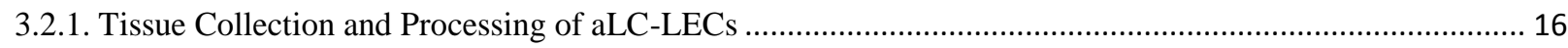

3.2.2. Tissue Fixation and Adherence by Viscoelastic material .................................................................. 16

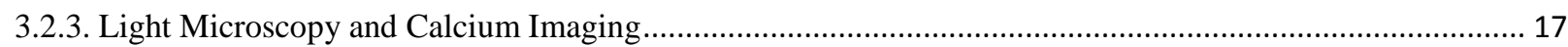

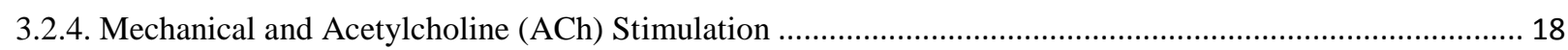

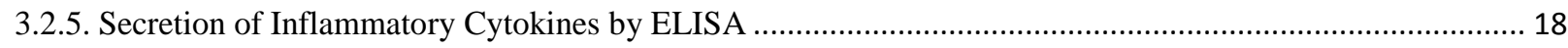

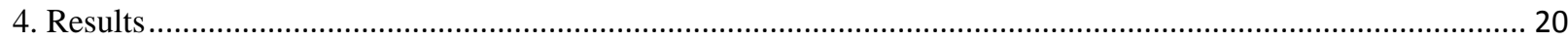

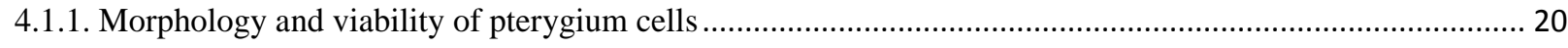

4.1.2. Flow cytometry of the long-term 3D cultures of pterygium containing outgrowing cells .............................. 21

4.1.3. Immunofluorescent staining of pterygium grafts and long-term cultivated 3D outgrowing cells ................. 22

4.1.4. ELISA measurement of proinflammatory cytokines IL-6 and 8 secreted from 3D outgrowing pterygium

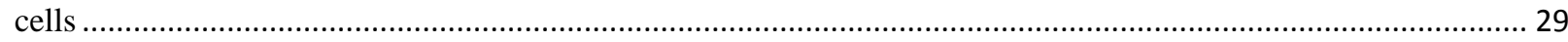

4.2.1. Human eye explant tissues adhere to the cell culture dish under a gravitational force of viscoelastic

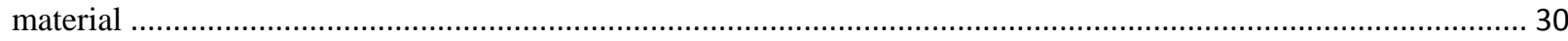

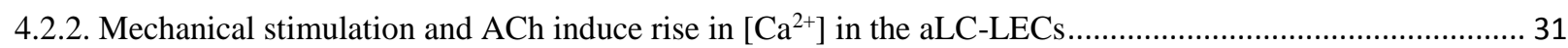

4.2.3. Measurement of proinflammatory/angiogenic factors secreted by the fvERM outgrowing cells upon TNF $\alpha$

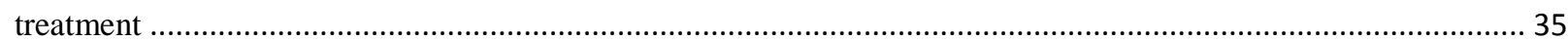

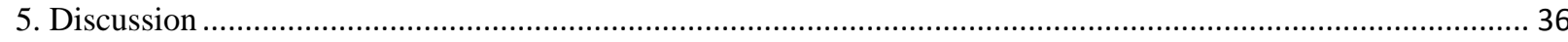

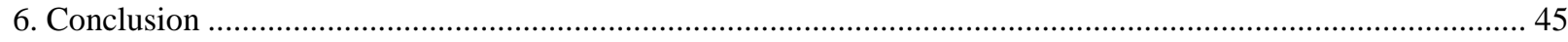

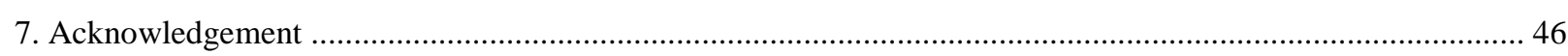

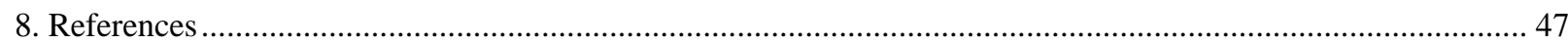




\section{List of abbreviations}

\begin{tabular}{|l|l|}
\hline ABCG-2 & ATP-binding cassette sub-family G member 2 \\
\hline ACh & Acetylcholine \\
\hline aLC & Anterior lens capsule \\
\hline AR & Aldose reductase \\
\hline AM & Acetoxymethyl \\
\hline APC & Allophycocyanin \\
\hline b-FGF & Basic fibroblast growth factor \\
\hline CAMs & Cell adhesion molecules \\
\hline CK19/8-18 & Cytokeratin \\
\hline CXCR4 & C-X-C chemokine receptor type 4 \\
\hline DMEM & Dulbecco-modified Eagle's medium \\
\hline DMSO & Dimethyl sulfoxide \\
\hline DAPI & 4',6-diamidino-2-phenylindole \\
\hline ECM & Extracellular matrix \\
\hline ELISA & Enzyme-linked immunosorbent assay \\
\hline EMT & Epithelial-Mesenchymal Transition \\
\hline FBS/FCS & Fetal bovine/calf serum \\
\hline FITC & Fluorescein isothiocyanate \\
\hline fvERMs & Fibrovascular epiretinal membranes \\
\hline hTERT & Human telomerase reverse transcriptase \\
\hline HMGB1 & High-mobility group box-1 \\
\hline HIF-1 $\alpha$ & Hypoxia-inducible factor 1-alpha \\
\hline ICB & Iris-ciliary body \\
\hline IL-6/IL-8 & Interleukin 6/8 \\
\hline LEC & Lens epithelial cell \\
\hline LESC & Limbal epithelial stem cell \\
\hline LPS & Lipopolysaccharide \\
\hline M1mAChR & Muscarinic receptors \\
\hline MMC & Mitomycin C \\
\hline MMP & Matrix metalloproteinases \\
\hline MSCs & Mesenchymal stem cells \\
\hline MUC1 & Mucin 1 \\
\hline nAChR & Nicotinic receptors \\
\hline NF- B & $\begin{array}{l}\text { Nuclear factor kappa-light-chain-enhancer of } \\
\text { activated B cells }\end{array}$ \\
\hline OCT-4 & Octamer-binding transcription factor 4 \\
\hline PBS & Phosphate buffered saline \\
\hline PDR & Proliferative diabetic retinopathy \\
\hline PI & Propidium Iodide \\
\hline PE & Proliferative diabetic retinopathy \\
\hline PDR & Proliferating cell nuclear antigen \\
\hline RPE & Retinal pigment epithelium \\
\hline
\end{tabular}




\begin{tabular}{|l|l|}
\hline SCs & Specific stem cells \\
\hline SD & Standard deviation \\
\hline Sox-2 & Sex determining region Y)-box 2 \\
\hline TGF & Transforming growth factor \\
\hline TNF $\alpha$ & Tumor necrosis factor alpha \\
\hline TUNEL & $\begin{array}{l}\text { Terminal deoxynucleotidyl transferase (TdT)- } \\
\text { mediated dUTP nick-end labeling }\end{array}$ \\
\hline$\Delta$ Np63 & Tumor protein p63 \\
\hline UV & Ultraviolet radiation \\
\hline Vim & Vimentin \\
\hline 8-OHdG & 8-hydroxy-2'-deoxyguanosine \\
\hline
\end{tabular}




\section{Summary}

Development of ex vivo models to study pathogenesis, inflammation and treatment modalities for different eye disorders such as pterygium, cataract and fibrovascular epiretinal membranes (fvERMs) from proliferative diabetic retinopathy (PDR) is much needed. A novel, simple, and reproducible method for cultivating such pathological tissues obtained from human eyes during surgery was hereby developed using viscoelastic material as a tissue adherent to facilitate cell attachment.

Pterygium obtained from surgery was cultivated until reaching 3D stratification over long periods of cultivation ex vivo (3 months). Surface profiling of the multi-layered outgrowing cells from the pterygium was performed to test for presence of hematopoietic- and mesenchymal- stem cell markers, as well as determine the origin of the outgrowing cells. Examination of these cells by immunohistochemistry using pluripotency, oxidative stress, stemness, migration and proliferation, epithelial and secretory markers was also performed, while the effect of anti-proliferative agent Mitomycin $\mathrm{C}$ upon secretion of pro-inflammatory cytokines IL-6 and IL-8 was assessed.

The 3D outgrowing cells from the pterygium showed high expression of migration- (CXCR4), secretory- (MUC1, MUC4) and oxidative damage- (8-OHdG) markers, and low expression of hypoxia- (HIF-1 $\alpha$ ) and proliferation- (Ki-67) markers. Moderate and low expression of the pluripotency markers (Vimentin and $\Delta \mathrm{Np63}$ ) was present, respectively, while the putative markers of stemness (Sox2, Oct4, ABCG-2) and epithelial cell markers- (CK19, CK8-18) were weakly expressed. The surface marker profile of the outgrowing cells revealed high expression of the hematopoietic marker CD47, mesenchymal markers CD90 and CD73, minor or less positivity for the hematopoietic marker CD34, mesenchymal marker CD105, progenitor marker CD117 and attachment protein markers. The 3D outgrowing cells secreted low levels of IL-6 and IL-8 ex vivo, which were inhibited upon Mitomycin C treatment.

The ex vivo tissue engineered pterygium consists of a mixture of cells of different lineage origin, suitable for use as a disease model for studying pathogenesis ex vivo, while opening possibilities for new treatment and prevention modalities.

Furthermore, anterior lens capsule-lens epithelial cells (aLC-LECs) from cataract surgery and fvERMs from human eyes undergoing vitrectomy for PDR were used. The aLC-LECs and the fvERM cells were expanded ex vivo in a 2D-monolayer culture. The aLC-LECs underwent calcium imaging upon challenge by mechanical and acetylcholine (ACh) stimulation, while the fvERM outgrowing cells underwent inflammatory studies.

The aLC-LECs stimulated by mechanical and ACh treatment showed active calcium signaling and presence of ACh receptors in these cells. The fvERMs could be activated to undergo an inflammatory response upon $\mathrm{TNF} \alpha$ treatment, which can surve as an ex vivo study model for studying PDR and inflammation in in vivo-like conditions. 


\section{Introduction}

The eye is a sensory organ protected from foreign materials by its curved architecture, compartmental organization, impermeable epithelium, tear secretion, and ocular drainage pathways. It is a slightly asymmetrical sphere with an approximate length of $24-25 \mathrm{~mm}$ and a transverse diameter of $24 \mathrm{~mm}$.

It is composed of three layers: 1) external layer or so called connective tissue, which consists of transparent cornea connected to white sclera via the limbus; 2) intermediate layer or vascular tissue composed of the choroid as well as the ciliary body in the middle connected by the iris in front of the globe; 3) internal layer or neural tissue constituted of the retina, which has the function of transmitting the electrical impulse to the brain through the optic nerve. There is also another important transparent entity inside the eye called the lens, located behind the iris and between the ciliary body. The eye consists of two segments, anterior segment which represents a smaller part of the eye and consists of the cornea, conjunctiva, iris-ciliary body (ICB), lens and aqueous humor, and posterior segment representing the major ocular structure consisting of the sclera, choroid, and retina surrounding the vitreous cavity filled with the vitreous humor (Fig. 1) (1, 2).

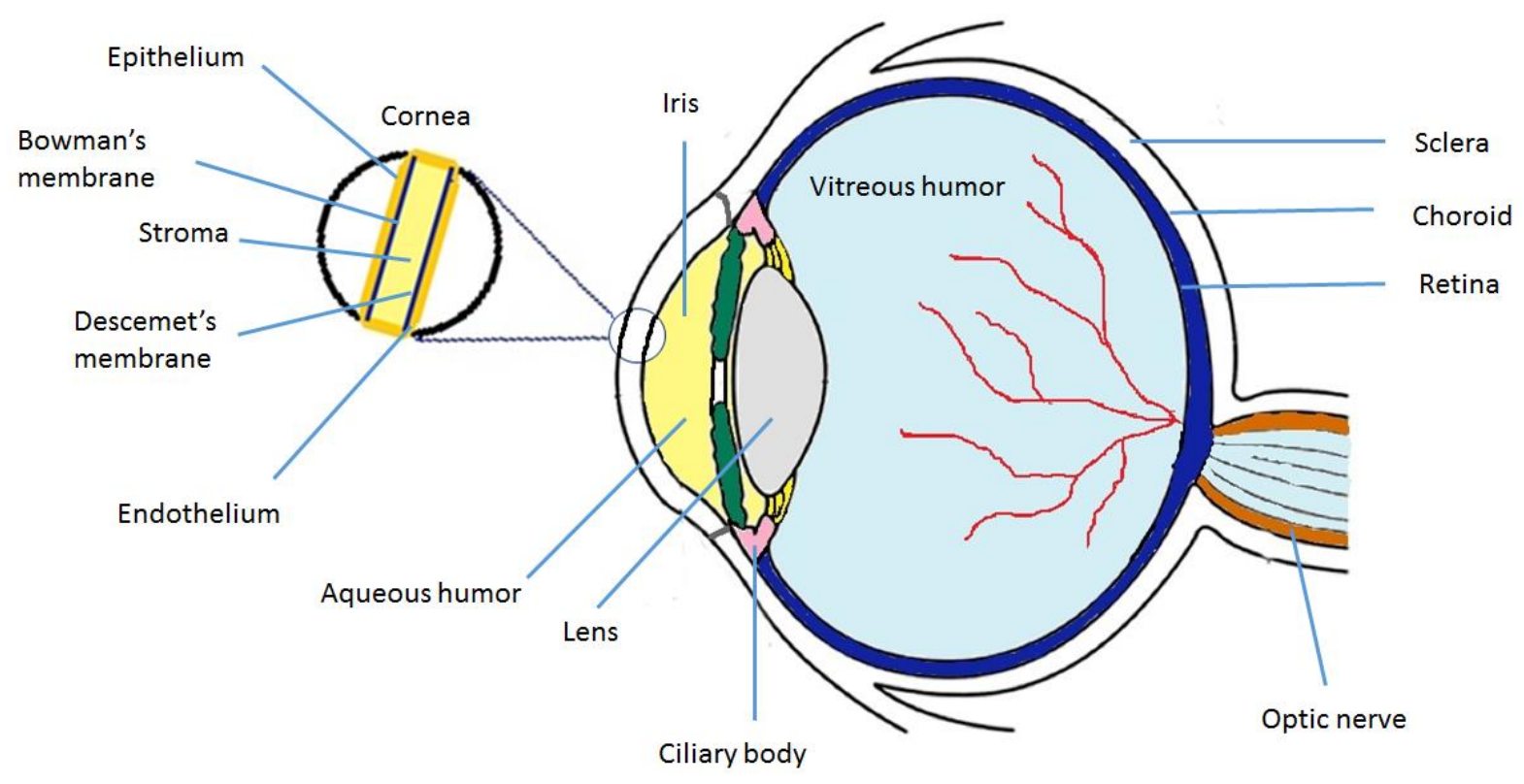

Figure 1. Anatomy of the eye 


\subsection{Conjunctiva}

The conjunctiva is a transparent mucous membrane lining the inner surface of the eyelids and the anterior surface of the globe, terminating at the corneoscleral rim. It has a dense lymphatic supply and an abundance of immunocompetent cells.

Between the cornea and conjunctiva, there is a junction called limbus which contains epithelial and stem cells - these act like a barrier which prevents outgrowing of the conjunctiva onto the cornea.

\subsection{Pterygium}

Pterygium is a triangular fibrovascular subepithelial ingrowth of degenerative bulbar conjunctival tissue over the limbus and onto the cornea, which is invasive and highly vascularized; it is believed to arise from activated and proliferating limbal epithelia stem cells (LESCs). The pathogenesis of this disorder remains uncertain, although it is thought to be mainly caused by ultraviolet (UV) radiation. Alternatively, a wide range of pathogenic factors have been proposed, including viral infections, epigenetic aberrations, epithelialmesenchymal transition, immunologic and anti-apoptotic mechanisms, angiogenic and lymphangiogenic stimulation, dysregulation of extracellular matrix (ECM) modulators and growth factors, inflammation cascades, recruitment of bone-marrow-derived stem- and progenitor cells, and modifications in the cholesterol metabolism. Most of these factors are related more to the development and maintenance of the disease than to its origin (3-5).

Sometimes pterygia can extend upon the pupillary axis and cause vision loss. They usually grow from the nasal side into the interpalbebral area (Fig. 2), possibly due to the sun's rays passing laterally through the cornea unobstructed, where they get refracted and become focused on the medial limbal area. When the sun's rays are passing medially, the shadow of the nose can act to reduce the intensity of sunlight focused on the lateral limbal area (6). If there is progression towards the visual axis or if the lesion is cosmetically unacceptable, then surgical excision is indicated. Recurrence is common after surgery, but it is reduced by complete excision with beta irradiation, Mitomycin C (MMC) in connection with conjunctival autografts or amniotic membrane transplantation (7-9). 


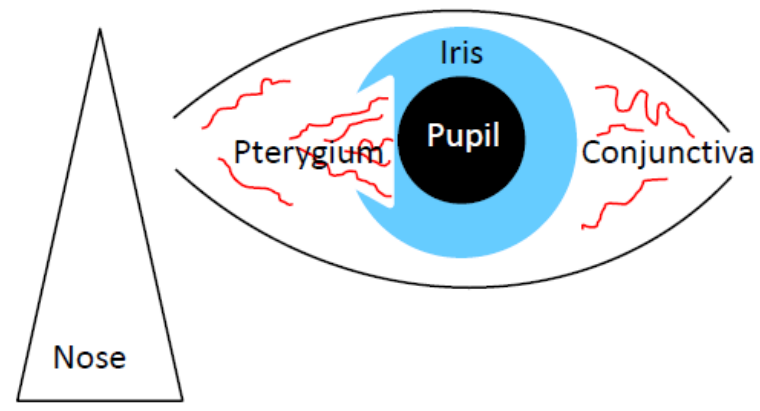

\section{Figure 2. Anatomy of the pterygium of the eye}

\subsection{Lens}

In order to accomplish its function of transmitting and focusing light, the crystalline lens of the vertebrate eye has evolved into a unique cellular structure and protein complement. Like the lens in a photo camera, the basic function of the lens of the eye is to transmit and focus light onto the retina. To facilitate this, it contains one of the highest concentrations of proteins of any tissue. As much as $60 \%$ of the total mass of the lens can be made up of proteins and water, much higher than almost any other tissue. Apart from that, it contains other constituents, such as lipids, amino acids, electrolytes, peptides and carbohydrates, that account for only $1 \%$ of the lens wet weight $(10,11)$.

The lens is transparent, devoid of blood supply and innervation at birth. It is composed of epithelial cells that differentiate into long fiber cells reaching the anterior and posterior poles of the lens.

The crystalline lens grows and changes its shape throughout life from a rounded ovoid in childhood, to a more flattened ovoid in old age. The lens contains capsule, which is an acellular and elastic structure that contains the growing mass of developing and differentiating lens cells, an anterior and equatorial layer of epithelium, a peripheral cortical region, and an inner nuclear core. The capsule acts as a barrier to diffusion and takes role in shaping the lens during accommodation. Its main components are type IV collagen, laminin, entactin, perlecan, type XVIII collagen, heparin sulfate proteoglycan, and fibronectin.

The anterior lens capsule (aLC) remains as a basement membrane supporting the lens epithelial cells (LECs), while the posterior capsule is a thin membrane that is merely adherent to the fiber cells growing along its inner surface. The thickness of the anterior capsule increases with age and the capsule is always thinnest posteriorly.

The cells located in the epithelium can divide and diferentiate into lens cell fibers, however, the remaining epithelium which does not normally divide has a role in transporting solutes between the lens and the aqueous humor. The anterior cuboidal epithelial cells of the lens allow exchange of low molecular-weight metabolites and ions. The cells are also rich in 
organelles and contain large amounts of cytoskeletal proteins such as microtubules, spectrin, $\alpha$-actinin, actin, myosin, and vimentin, presumably to help stabilize the cell structures during accommodation. Both LECs and especially fiber cells contain large amounts of crystallins (10-12).

\subsection{Cataract of the lens}

Cataract refers to any opacity of various degree of the crystalline lens, which in normal conditions is almost completely transparent (Fig. 3). During aging, the lens increases in overall size and loses the ability to accommodate. Continued growth of the lens fibers with aging causes the nucleus to become compressed and less flexible. Furthermore the proteins of the nuclear lens start to aggregate and produce pigmentation to decrease the transparency causing the lens nucleus to appear yellow or brown where there is excess pigmentation. Cataractous changes can involve any of the structures of the lens like the nucleus and cortex, as well as anterior and posterior subcapsular areas (13).

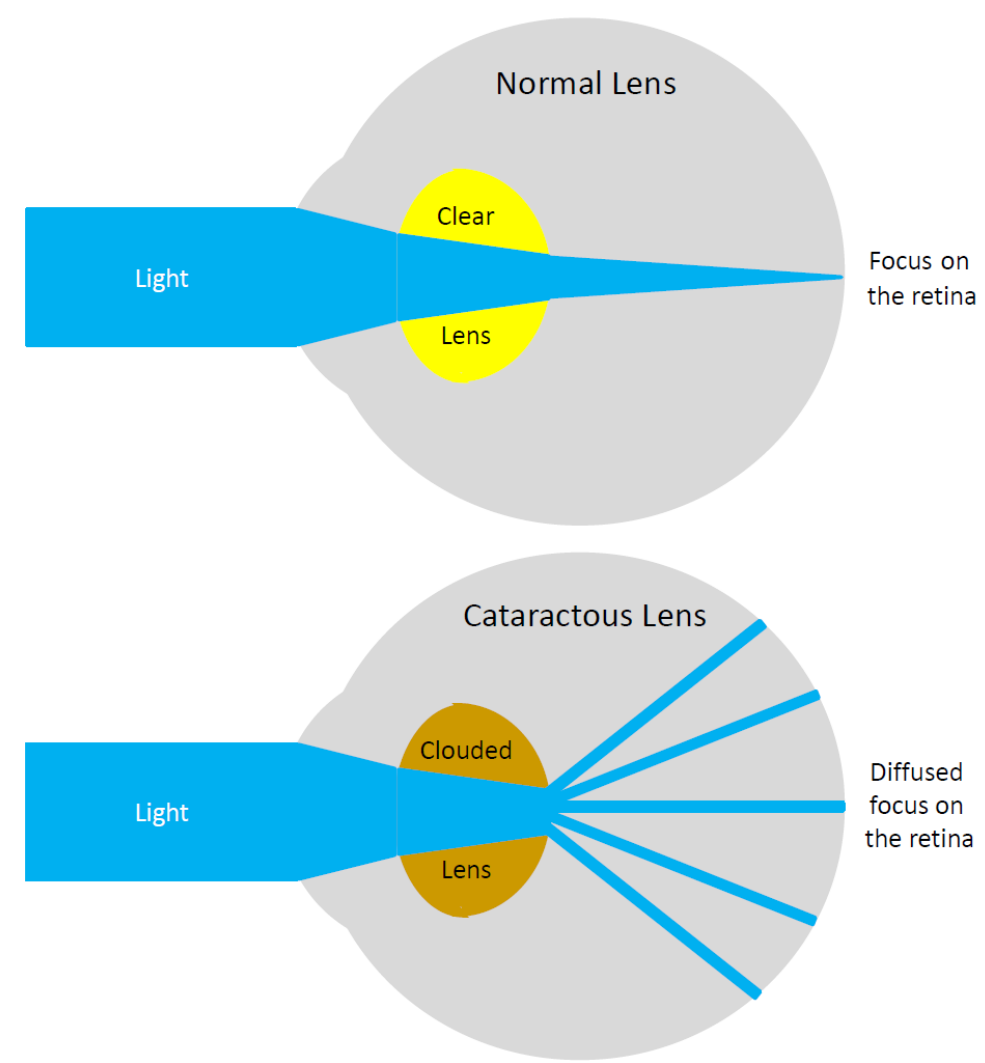

Figure 3. Normal vs. lens affected by cataract 


\section{Aims of the study}

1. To adherently cultivate ex vivo three types of tissues: pterygium, aLCs containing LECs and a pathologic fibrovascular tissue/fibrovascular epiretinal membranes (fvERMs).

2. To achieve $2 \mathrm{D}$ and/or $3 \mathrm{D}$ outgrowth of cells from the cultivated tissues and to characterize molecularly these cells upon different treatments, as well as measure the secretion of inflammatory/pro-angiogenic cytokines (IL-6 and IL-8) from them.

3. To investigate the surface marker phenotype of the pterygium outgrowing cells using markers for hematopoietic and mesenchymal stem cells (MSCs), as well as cell adhesion molecules (CAMs) in order to determine the possible origin of the cells.

4. To measure intracellular calcium dynamics upon mechanical stimulation, as well as calcium signalling and intercellular communication upon Acetylcholine (ACh) stimulation in aLCs containing LECs. 


\section{Materials and methods}

\subsubsection{Pterygium harvesting and cultivation}

All tissue collection complied with the Guidelines of the Helsinki Declaration and was obtained from surgery following a patient signed consent. The tissue harvesting was approved by the Local Committee for Medical Research Ethics at University of Oslo. The removed graft after surgery was cultivated in 24-well cell culture plates using Dulbecco-modified Eagle's medium (DMEM) supplemented with $4.5 \mathrm{~g}$ glucose/L, $10 \%$ fetal bovine serum (FBS), 200mM/mL L-glutamine (Sigma-Aldrich, Germany), and 1\% antibiotic/antimycotic solution (PAA, Pasching, Austria). To gravitationally press down the explanted tissue, viscoelastic material (ProVisc, Alcon, Fort Worth, TX, USA) was used as discovered and described for the first time by our group. The viscoelastic was added on top of the explant to allow flattening and adherence of the tissue onto the surface of the well. The goal was to develop stratified or 3D structure of the outgrowing cells from the pterygium over more than three months, with medium change being performed each other day. The 3D cell structure which was formed could easily be lifted from the cell culture plate by Colibri forceps at the end of the cultivation period and before fixation for further analysis.

\subsubsection{Cell viability assay}

Cell viability of the long-term 3D cultures of the pterygium was determined using Annexin VFluorescein isothiocyanate (FITC)/Propidium Iodide (PI) assay (MBL International, Woburn, MA, USA), as well as the trypan blue exclusion test (Sigma Aldrich, MO, USA). For both assays, the cells were collected by trypsinization in the same culture media, then centrifuged and resuspended in Binding Buffer for the Annexin V-FITC/PI assay or phosphate buffered saline (PBS) for the trypan blue test. The cells were stained with Annexin V-FITC, PI, and Annexin V-FITC/PI, then analyzed by Flowing Software 2.5 (PerttuTerho, Turku Centre for Biotechnology, University of Turku, Finland). Alternatively, cells suspended in 50 $\mu$ L PBS were stained by equal part of trypan blue solution and counted in a Hemocytometer (Bürker chamber).

\subsubsection{Immunophenotyping of cells}

Flow cytometry was performed on the long-term 3D cultures of pterygium containing outgrowing cells to determine their immunophenotype. Three antibodies conjugated with 
FITC-, R-phycoerythrin (PE)- and allophycocyanin (APC) were used to measure the expression of CD34, CD44, CD90/Thy-1, CD73, CD105 and CD166/ALCAM (all from Biolegend, San Diego, CA, USA); CD47, CD117/c-kit, CD146/MCAM, CD112 (all from R\&D Systems, Minneapolis, MN, USA) (for further details refer to Table 1). The prepared samples were measured by FACS Calibur flow cytometer (BD Biosciences Immunocytometry Systems) and data were analysed by Flowing Software 2.5 (PerttuTerho, Turku Centre for Biotechnology, University of Turku, Finland).

Table 1. List of antibodies used for FACS analysis

\begin{tabular}{l|ccl}
\hline \multicolumn{1}{c|}{ Antibody } & Clone & $\begin{array}{c}\text { Catalog } \\
\text { No. }\end{array}$ & Company \\
\hline CD34 & 581 & 343504 & BioLegend \\
CD44 (H-CAM) & BJ18 & 338804 & BioLegend \\
CD90/Thy-1 & $5 E 10$ & 328108 & BioLegend \\
CD73 & AD2 & 344004 & BioLegend \\
CD105 & 323206 & $43 A 3$ & BioLegend \\
CD47 & 472603 & FAB4670A & R\&D Systems \\
CD117 (c-kit) & 47233 & FAB332P & R\&D System \\
CD146 (MCAM) & 128018 & FAB932A & R\&D System \\
CD166 (ALCAM) & $3 A 6$ & 343904 & BioLegend \\
CD112 (Nectin-2) & 610603 & FAB2229A & R\&D System \\
\hline
\end{tabular}

\subsubsection{Immunofluorescent staining}

For the immunofluorescent staining experiment, we wanted to compare expression of different markers on the pterygium obtained right after surgery and that cultivated as longterm 3D cultures. Therefore in both of the cases the tissues were collected and fixed in $4 \%$ paraformaldehyde at room temperature, later dehydrated in ascending alcohol series and embedded in paraffin; $3-4 \mu \mathrm{m}$ thick tissue sections were prepared using a rotary microtome, then mounted onto histological slides. After heat-induced antigen retrieval with Tris/EDTA or Citrate buffer and blocking, immunofluorescent labelling with primary antibodies was performed. The samples were characterized for markers of pluripotency and stemness (Vimentin (Vim), Tumor protein p63 ( $\Delta$ Np63), SRY (sex determining region Y)-box 2 (Sox2), octamer-binding transcription factor 4 (Oct4), ATP-binding cassette sub-family G member 2 (ABCG-2)), oxidative stress (8-hydroxy-2'-deoxyguanosine (8-OHdG), Hypoxiainducible factor 1-alpha (HIF-1 $\alpha)$ ), migration and proliferation- (C-X-C chemokine receptor type 4 (CXCR4) and Ki-67), epithelial- (cytokeratin-19 (CK19) and 8-18) and secretory 
markers (Mucin (MUC1) and MUC4) (Table 2 summarizes the primary antibodies and dilutions used for immunofluorescent staining). In continuation secondary antibody Alexa 488 (green) or Cy3 (red) was used. Nuclear staining was performed using 4',6-diamidino-2phenylindole (DAPI). Fluorescent images were taken by a ZEISS Axio Observer.Z1 (ZEISS, Oberkochen, Germany) microscope. The quantification of positive cells was carried out using standard ImageJ software by three independent individuals. The number of positive cells on the full field of view was taken into account with the help of nuclear (DAPI) staining. Multiple pictures were taken of each sample and the results averaged out as mean \pm standard deviation (SD).

Table 2. Details of the antibodies used for immunohistochemistry

\begin{tabular}{|c|c|c|c|c|c|}
\hline Antibody & Catalog No. & Company & Clonality & Antigen & Dilution \\
\hline ABCG-2 & b7059 & $\begin{array}{l}\text { Sigma } \\
\text { Aldrich }\end{array}$ & $\begin{array}{c}\text { Mouse } \\
\text { monoclonal }\end{array}$ & $\begin{array}{c}\text { Fusion protein } \\
\text { containing human } \\
\text { BCRP }\end{array}$ & $1: 50$ \\
\hline $\begin{array}{c}\text { CK8 } \\
\text { CK18 }\end{array}$ & ab17139 & Abcam & $\begin{array}{c}\text { Mouse } \\
\text { monoclonal }\end{array}$ & $\begin{array}{c}\text { Cytokeratins from } \\
\text { the human breast } \\
\text { carcinoma cell line } \\
\text { MCF-7 }\end{array}$ & $1: 50$ \\
\hline CK19 & sc-33119 & Santa Cruz & $\begin{array}{c}\text { Goat } \\
\text { polyclonal }\end{array}$ & $\begin{array}{l}\text { Peptide mapping at } \\
\text { the } \mathrm{N} \text {-terminus of } \\
\text { CK19 of human } \\
\text { origin }\end{array}$ & $1: 50$ \\
\hline CXCR4 & ab7199 & Abcam & $\begin{array}{c}\text { Rabbit } \\
\text { polyclonal }\end{array}$ & $\begin{array}{c}\text { Recombinant } \\
\text { fragment } \\
\text { corresponding to Rat } \\
\text { CXCR4 aa 2-38 (N } \\
\text { terminal) }\end{array}$ & $1: 100$ \\
\hline $\mathrm{HIF}-1 \alpha$ & NB100-105 & Novus & $\begin{array}{c}\text { Mouse } \\
\text { monoclonal }\end{array}$ & $\begin{array}{l}\text { Fusion protein } \\
\text { containing amino } \\
\text { acids } 432-528 \text { of } \\
\text { human HIF-1- } \alpha\end{array}$ & $1: 50$ \\
\hline $\mathrm{Ki}-67$ & RM-9106-S & $\begin{array}{l}\text { Thermo } \\
\text { Scientific }\end{array}$ & $\begin{array}{c}\text { Rabbit } \\
\text { monoclonal }\end{array}$ & $\begin{array}{l}\text { Synthetic peptide } \\
\text { derived from human } \\
\text { Ki- } 67 \text { protein }\end{array}$ & $1: 200$ \\
\hline MUC1 & M32250M & $\begin{array}{c}\text { Life } \\
\text { science }\end{array}$ & $\begin{array}{c}\text { Mouse } \\
\text { monoclonal }\end{array}$ & $\begin{array}{l}\text { High molecular } \\
\text { weight glycoprotein } \\
\text { from human milk-fat } \\
\text { globule molecule }\end{array}$ & $1: 50$ \\
\hline MUC4 & $34-4900$ & Zymed & $\begin{array}{c}\text { Mouse } \\
\text { monoclonal }\end{array}$ & $\begin{array}{l}\text { Protein coding, } \\
\text { encodes an integral } \\
\text { membrane } \\
\text { glycoprotein on the } \\
\text { cell surface }\end{array}$ & $1: 50$ \\
\hline
\end{tabular}




\begin{tabular}{|c|c|c|c|c|c|}
\hline Oct4 & ab19857 & Abcam & $\begin{array}{l}\text { Rabbit } \\
\text { polyclonal }\end{array}$ & $\begin{array}{l}\text { Synthetic peptide } \\
\text { conjugated to KLH } \\
\text { derived from within } \\
\text { residues } 300 \text { to the } \\
\text { C-terminus of } \\
\text { Human Oct4 }\end{array}$ & $1: 100$ \\
\hline p63 alpha & 4892 & $\begin{array}{c}\text { Cell } \\
\text { Signaling } \\
\text { Technology }\end{array}$ & $\begin{array}{c}\text { Rabbit } \\
\text { polyclonal }\end{array}$ & $\begin{array}{c}\text { Detects endogenous } \\
\text { levels of total } \\
\text { p63alpha protein }\end{array}$ & $1: 100$ \\
\hline Sox 2 & ab75485 & Abcam & $\begin{array}{c}\text { Mouse } \\
\text { monoclonal }\end{array}$ & $\begin{array}{l}\text { Recombinant full } \\
\text { length protein } \\
\text { corresponding to } \\
\text { Human Sox } 2\end{array}$ & $1: 50$ \\
\hline Vimentin & RM-9120-S & $\begin{array}{l}\text { Thermo } \\
\text { Scientific }\end{array}$ & $\begin{array}{c}\text { Rabbit } \\
\text { monoclonal }\end{array}$ & $\begin{array}{l}\text { Recombinant protein } \\
\text { encoding human } \\
\text { vimentin }\end{array}$ & $1: 200$ \\
\hline 8-OHdG & Sc66036 & Santa Cruz & $\begin{array}{c}\text { Mouse } \\
\text { monoclonal }\end{array}$ & $\begin{array}{l}\text { Raised against (8- } \\
\text { OHdG)-BSA and } \\
\text { casein conjugates }\end{array}$ & $1: 100$ \\
\hline
\end{tabular}

\subsubsection{Secretion of Inflammatory Cytokines by ELISA}

For measuring the secretion of inflammatory cytokines we used the same high glucosecontaining DMEM medium only this time supplemented with 5\% FBS in order to diminish its possible influence on the secretion of the cytokines. The medium was applied to the $3 \mathrm{D}$ outgrowing cells and kept for $24 \mathrm{~h}$. After the supernatants were collected. In addition, treatment of the cells with $0.5 \mathrm{mg} / \mathrm{mL}$ MMC (Kyowa, Takeda Belgium-Brussels) was applied for $20 \mathrm{~min}$ and supernatant collected. LESC cultures cultivated in high glucose-containing medium with $20 \%$ FBS were used as a control. The secreted cytokines, Interleukin 6 (IL-6) and IL-8, were analysed by a commercial enzyme-linked immunosorbent assay (ELISA) kit (R\&D, Germany) according to the manufacturer's protocol. Three independent experiments were performed on outgrowing cells from four different pterygium donors.

\subsubsection{Statistical analysis for the pterygium study}

Each experiment was performed at least three times and each sample was tested in triplicates.

Data are expressed as mean \pm standard deviation (SD). Statistically significant differences were determined by student-t tests, a p-value $\leq 0.05$ was regarded significant. 


\subsubsection{Tissue Collection and Processing of aLC-LECs}

All tissue collection complied with the Guidelines of the Helsinki Declaration and was approved by the National Medical Ethics Committee of Slovenia; following a patient signed consent before surgery which was performed at the Eye Hospital, University Medical Centre (UMC), Ljubljana, Slovenia. Altogether 11 patients were included in this study - 6 cultures were analyzed for mechanical stimulation and 5 cultures for ACh stimulation, with the patients' age ranging from 70 to 92 years.

The aLC explants consisted of a monolayer of LECs attached to the basal lamina and were obtained from uneventful cataract surgeries due to progredient cataract. Lenses were dissected so that the aLCs (i.e., basal lamina and associated LECs) were isolated from the fiber cells that form the bulk of the lens. FvERMs were obtained from patients undergoing vitrectomy due to intravitreal hemorrhage in proliferative diabetic retinopathy (PDR).

All explants obtained were placed in a single dish accordingly. Immediately after isolation, the excised human eye explants were placed in sterile tubes filled with DMEM:F12 (D8437, Sigma-Aldrich, Ayrshire, UK), supplemented with 10\% fetal calf serum (FCS) (PAA Laboratories GmbH, Pasching, Austria),. The explants were then transferred to empty cell culture glass bottom Petri dishes (Mattek Corp., Ashland, MA, USA; $3.5 \mathrm{~cm}$ in diameter) or tissue culture 12-well plates (TPP, Sigma, Germany) by using microdissecting tweezers (WPI by Dumont, Med.Biologie, Germany). The aLC explants were placed into the culture dish so that the concave side with the LECs was on the top and oriented upwards. The time of culturing ranged from 6 to 48 days.

\subsubsection{Tissue Fixation and Adherence by Viscoelastic material}

For obtaining adherent conditions, careful removal of the remaining medium from the tissue cultures was performed by a micropipette, and then viscoelastic (HEALON OVD, Abbott Medical Optics, USA) was added on top of the explant to allow for flattening or "ironing" of the tissue onto the surface of the Petri dish (Fig. 12). The next step was carefully applying the DMEM:F12 medium supplemented with 10\% FCS not to disturb the already added viscoelastic cover on top of the explants. For that, the micropipette tip was positioned close to the culture dish surface but far away from the explant, so that the medium arrived softly in contact with the viscoelastic and did not move the explant from its location. The culture dishes were then kept in a $\mathrm{CO}_{2}$ incubator (Innova CO-48; New Brunswick Scientific, Edison, $\mathrm{NJ}, \mathrm{USA}$ ) at $37^{\circ} \mathrm{C}$ and $5 \% \mathrm{CO}_{2}$. In order to allow the cells to attach and start proliferating out 
of the explant we were not moving the culture dish from the incubator for 2-3 days. During medium change, the medium was removed gently and a fresh one was added subsequently by a micropipette from the opposite side of the explant in the dish, the pipette tip being close to the surface of the dish all the time. The viscoelastic dissolved over time and got replaced by new medium - time by which the explant was fully attached to the surface of the culture dish.

\subsubsection{Light Microscopy and Calcium Imaging}

After culturing the cells were followed and their proliferation and migration were recorded throughout their continued growth using inverted light microscope (Axiovert S100, Carl Zeiss, AG, Oberkochen, Germany). The same microscope was used for $\left[\mathrm{Ca}^{2+}\right]_{\mathrm{i}}$ measurements. Image acquisition was carried out by a 12-bit cooled CCD camera SensiCam (PCO Imaging AG, Kelheim, Germany). The software used for the acquisition was WinFluor (written by J. Dempster, University of Strathclyde, Glasgow, UK). Microscope objectives used were 4x/0.10 Achroplan, 10x/0.30 Plan-Neofluar, 40x/0.50 LD A-plan, and 63x/1.25 oil PlanNeofluar (Zeiss).

The excitation filters used were mounted on a Lambda LS-10 filter wheel (Sutter Instruments Co., CA, USA) and had a wavelength of 360 and $380 \mathrm{~nm}$ (Chroma Technology Corp., Bellows Falls, VT, USA). Excitation with the $360 \mathrm{~nm}$ filter (close to the Fura-2 isosbestic point) allowed observation of the cells' morphology and of the changes in the concentration of the dye, irrespective of the changes in $\left[\mathrm{Ca}^{2+}\right]_{\mathrm{i}}$, while the $360 / 380 \mathrm{~nm}$ ratio allowed visualization of the $\left[\mathrm{Ca}^{2+}\right]_{i}$ changes in the cytoplasm. Image acquisition, timing, and filter wheel operation were all controlled by WinFluor software via a PCI6229 interface card (National Instruments, Austin, TX, USA). The light source used was XBO-75W (Zeiss) Xe arc lamp. The light intensity was attenuated when necessary with grey filters with optical densities 0.5, 1, and 2 (Chroma Technology Corp., Bellows Falls, VT, USA). The criteria for selecting the region for imaging were the presence of adherent cells and good cell morphology both assessed by observation of transilluminated and $360 \mathrm{~nm}$ fluorescence images. Individual image frames were acquired every $500 \mathrm{~ms}$ resulting in frame cycles being 1 second long (two wavelengths).

For $\left[\mathrm{Ca}^{2+}\right]_{i}$ monitoring, the cell cultures were loaded with the acetoxymethyl (AM) ester of Fura-2 (Fura-2 AM, Invitrogen-Molecular Probes, Carlsbad, CA, USA), intracellular calcium indicator. For loading, Fura-2 AM in dimethyl sulfoxide (DMSO) was suspended in $3 \mathrm{~mL}$ of 
medium (high glucose medium with FBS) or physiological saline with (in $\mathrm{mM}$ ) $\mathrm{NaCl}$ (131.8), $\mathrm{KCl}$ (5), $\mathrm{MgCl}_{2}$ (2), $\mathrm{NaH}_{2} \mathrm{PO}_{4}$ (0.5), $\mathrm{NaHCO}_{3}$ (2), $\mathrm{CaCl}_{2}$ (1.8), HEPES (10), glucose (10), $\mathrm{pH}$ 7.24 to the final working concentration of $2 \mu \mathrm{M}$ (aLC). The loading was done in the incubator at $37^{\circ} \mathrm{C}$ for $30 \mathrm{~min}$ (aLC). After loading, the cell cultures were washed twice for $7 \mathrm{~min}$ with the medium or physiological saline. The final working concentration of Fura-2 and the time of incubation/washing were larger for larger eye explants (it depended on the explant size).

Fura-2 dye has two excitation (absorption) peaks (340 and $380 \mathrm{~nm}$ ), an isosbestic point at $360 \mathrm{~nm}$ and one emission peak at $510 \mathrm{~nm}$. Its absorption and fluorescent properties change in accordance with $\mathrm{Ca}^{2+}$ binding (low $\left[\mathrm{Ca}^{2+}\right]_{\mathrm{i}}$ - high absorption at $380 \mathrm{~nm}$, high $\left[\mathrm{Ca}^{2+}\right]_{\mathrm{i}}$ - high absorption at $340 \mathrm{~nm}$ while the absorption is not $\mathrm{Ca}^{2+}$ dependent at the isosbestic point of $360 \mathrm{~nm}$ ). The absorptive properties of Fura-2 allow the use of ratio imaging (360/380 ratio), which considerably reduces the effects of uneven dye loading, leakage of the dye, and photobleaching as well as problems associated with measuring $\left[\mathrm{Ca}^{2+}\right]_{i}$ in cells of unequal thickness.

\subsubsection{Mechanical and Acetylcholine (ACh) Stimulation}

Further responses to mechanical stimuli were tested, and for that was used a tip of a glass micropipette mounted on a MP-285 micromanipulator (Sutter, Novato, CA, USA). Prior to use, the tip of the pipette was heat-polished until it rounded up.

The agonist acetylcholine (ACh; Sigma, USA) was applied in $10 \mu \mathrm{M}$ concentration, which was enough to induce $>90 \%$ maximal $\left[\mathrm{Ca}^{2+}\right]_{\mathrm{i}}$ response, according to the data by Collison et al. [12]. The agonist application as well as its washout from the bath was driven simply by the hydrostatic pressure of a $35 \mathrm{~cm}$ of water column and controlled manually by a luer-lock stopcock (WPI) and applied through a polyethylene plastic tubing (inner diameter $2 \mathrm{~mm}$ ), attached to the coarse micromanipulator. The excess bathing solution was removed by a suction line.

\subsubsection{Secretion of Inflammatory Cytokines by ELISA}

Secretion of inflammatory cytokines IL-6 and IL-8 from fvERM and aLC-LECs upon TNF $\alpha$ was measured. Therefore the expanded fvERM cells and aLC-LECs were plated onto 6-well plates at a density of $2 \times 10^{5}$ cells per well in triplicates and kept until proper cell number was achieved for cytokine measurements. After $24 \mathrm{hrs}$, the medium was changed, and the cells 
were treated with $100 \mathrm{ng} / \mathrm{mL}$ recombinant human Tumor necrosis factor alpha (TNF $\alpha$ ) (Preprotech, Rocky Hill, NJ, USA) for additional 24 hours. The secreted cytokines, IL-6, and IL-8 were analyzed by commercial ELISA kit (R\&D, Germany) according to the manufacturer's protocol. Three independent experiments were performed on outgrowing cells from three different donors both fvERM and aLC. 


\section{Results}

\subsubsection{Morphology and viability of pterygium cells}

Pterygium consists of mixture of cells and the morphology depends mostly on two types of cells: fibroblastic which are long-shaped (Fig.4, Aa), and squamous epithelial cells tightly packed together (Fig.4, Ab). After long term cultivation, pterygium formed spontaneous multi-layered structure that was easily tangible and removable from the plate for further analysis (Fig.4, Ac). The viability of the outgrowing cells tested by the Annexin V-FITC/PI assay and Trypan blue method was $(98.6 \pm 1.7 \%$ and $82.6 \pm 6.9 \%)$, respectively (Fig. 4, B) showing that the cells were enough viable to continue with further analysis.

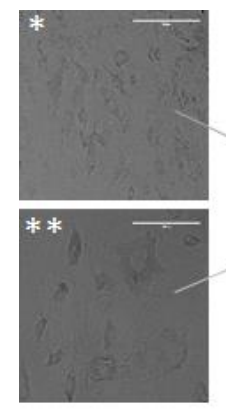

A
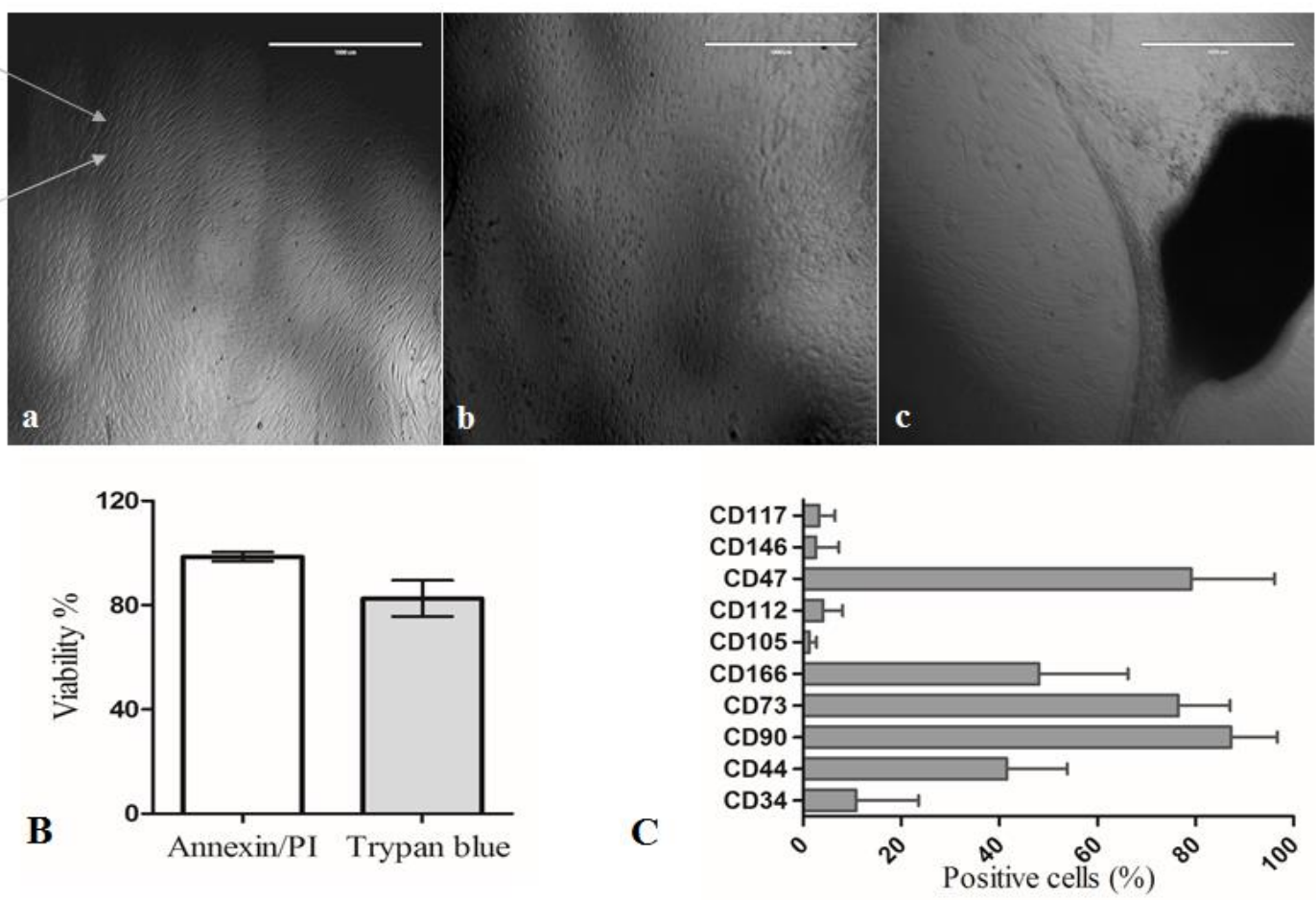

Figure 4. Cell morphology, viability and phenotyping of the cultivated pterygium. Fibroblastic cells (Aa), pterygium epithelial cells (Ab) and graft with outgrowing cells forming 3D layered structure (Ac) (Magnification: 10x, $\left({ }^{*}\right): 20 \mathrm{x}$ and $\left(^{* *}\right)$ : 40x). Cellular viability of the 3D outgrowing cells from the pterygium using Annexin V-FITC/PI assay and Trypan blue exclusion test (B). Cell surface markers phenotyping of the 3D outgrowing cells by FACS analysis; a plot of the percent positive cells versus different markers is shown as mean \pm SD $(C)$. 


\subsubsection{Flow cytometry of the long-term 3D cultures of pterygium containing outgrowing cells}

The expression of hematopoietic cell surface markers CD34 and CD47 was $(10.8 \pm 12.7 \%$ and $79.1 \pm 17 \%$ ), respectively. CD117/c-kit, a progenitor cell marker was low (3.3 $\pm 3.2 \%)$, while a very high expression of the MSC markers CD90 (87.2 $\pm 9.5 \%)$ and CD73 (76.4 $\pm 11 \%)$ were measured, in contrast to the MSC marker CD105 which was $(1.3 \pm 1.4 \%)$. The expression of ECM attachment proteins, which is important for the maintenance of the cellular growth were tested next: CD146/MCAM (2.6 $\pm 4.7 \%)$, CD166/ALCAM (48.1 $\pm 18.1 \%)$, CD112/Nectin-2 $(4.1 \pm 4 \%)$ and CD44/homing-associated cell adhesion molecule (H-CAM) (41.5 $\pm 12.3 \%)$ (Fig. 4, C). Expression of surface markers in \% are summarized in (Table 3).

Table 3. Immunophenotyping of the multi-layered outgrowing pterygium cells.

Expression of different surface markers in \%.

Multi-layered outgrowing pterygium cells

\begin{tabular}{lll}
\hline HSC markers & CD34 & $10.8 \pm 12.7 \%$ \\
& CD47 & $79.1 \pm 17 \%$ \\
Progenitor markers & CD117/c-kit & $3.3 \pm 3.2 \%$ \\
\hline \multirow{2}{*}{ MSC markers } & & \\
& CD90 & $87.2 \pm 9.5 \%$ \\
& CD73 & $76.4 \pm 11 \%$ \\
ECM attachment proteins & CD146/MCAM & $2.6 \pm 4.7 \%$ \\
& CD166/ALCAM & $48.1 \pm 18.1 \%$ \\
\hline markers & CD44/H-CAM & $41.5 \pm 12.3 \%$ \\
& CD112/Nectin-2 & $4.1 \pm 4 \%$ \\
\hline
\end{tabular}




\subsubsection{Immunofluorescent staining of pterygium grafts and long- term cultivated 3D outgrowing cells}

Immunofluorescent staining of a wide range of markers involved in the different pathways were examined in the pterygium grafts obtained directly from surgery and compared to those from long-term cultivated 3D outgrowths from the pterygia.

The expression of pluripotency markers (Vim and $\Delta \mathrm{Np} 63)$ was $(26.5 \pm 3.5 \%$ and $13.9 \pm 0.9 \%)$, respectively, in the pterygium graft tissue only, and (43.7 $\pm 4 \%$ and $12.3 \pm 1.5 \%)$, respectively, in the multi-layered outgrowing cells (Fig. 5), while other stemness markers (Sox2, Oct4 and ABCG-2) showed positivity in $(22.2 \pm 0.9 \%, 34.2 \pm 1.6 \%$ and $25 \pm 5 \%)$ of the cells, respectively, in the pterygium graft itself, and $(15.3 \pm 0.6 \%, 39.2 \pm 2.5 \%$ and $32.7 \pm 6.6 \%)$, respectively, within the multi-layered outgrowing cells (Fig. 6).
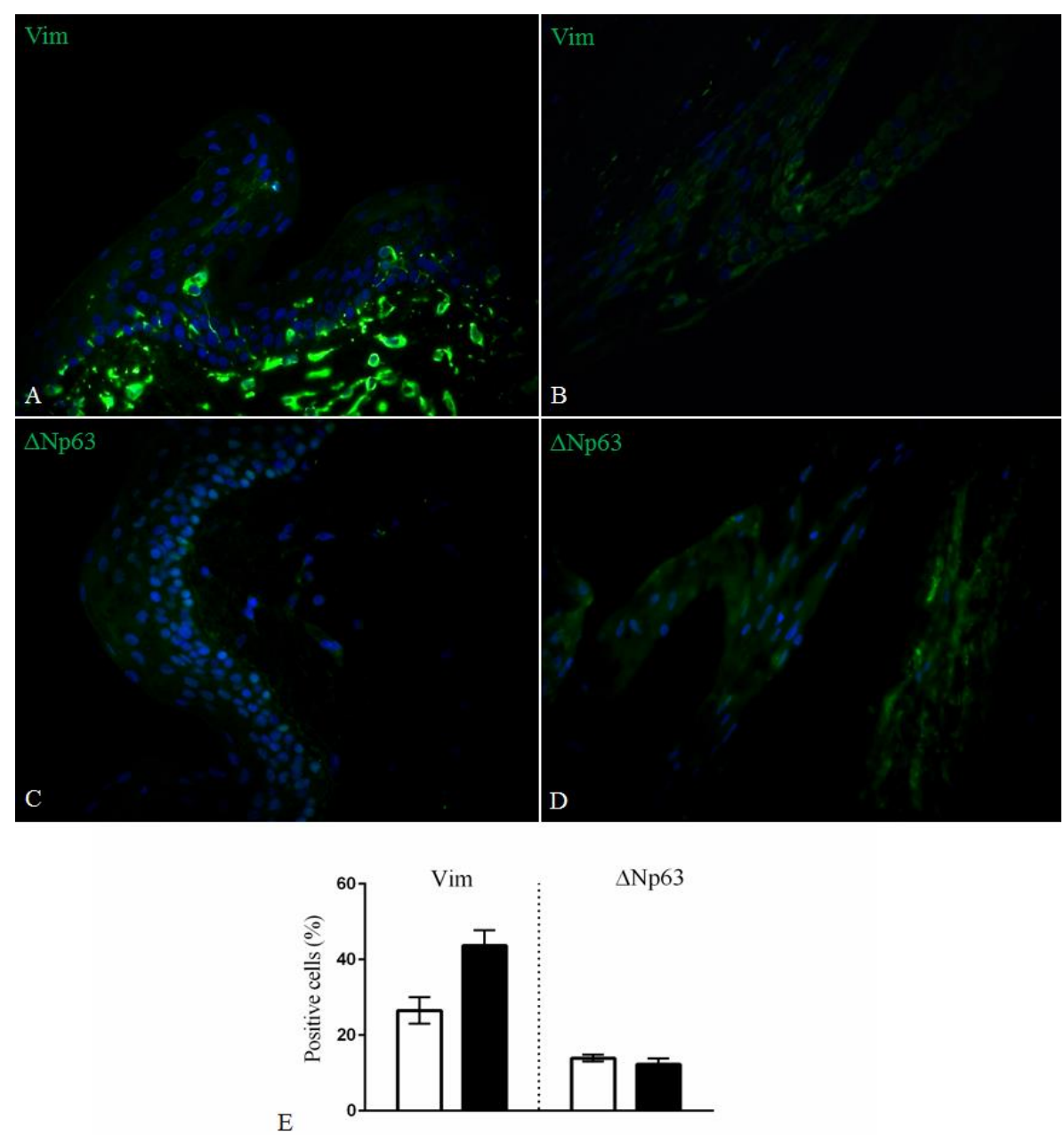

Figure 5. Pterygium tissue and 3D outgrowing cells stained for pluripotency markers.

Pterygium tissue-containing cultures $(\mathrm{A}, \mathrm{C})$, and outgrowing cells forming 3D structures (B, D) were stained for Vim and $\Delta \mathrm{Np} 63$, respectively (Magnification: 40x). White bar represents 
data from pterygium tissue, while the black bar shows results from independently grown 3D outgrowing cells. Data are expressed as mean \pm SD.

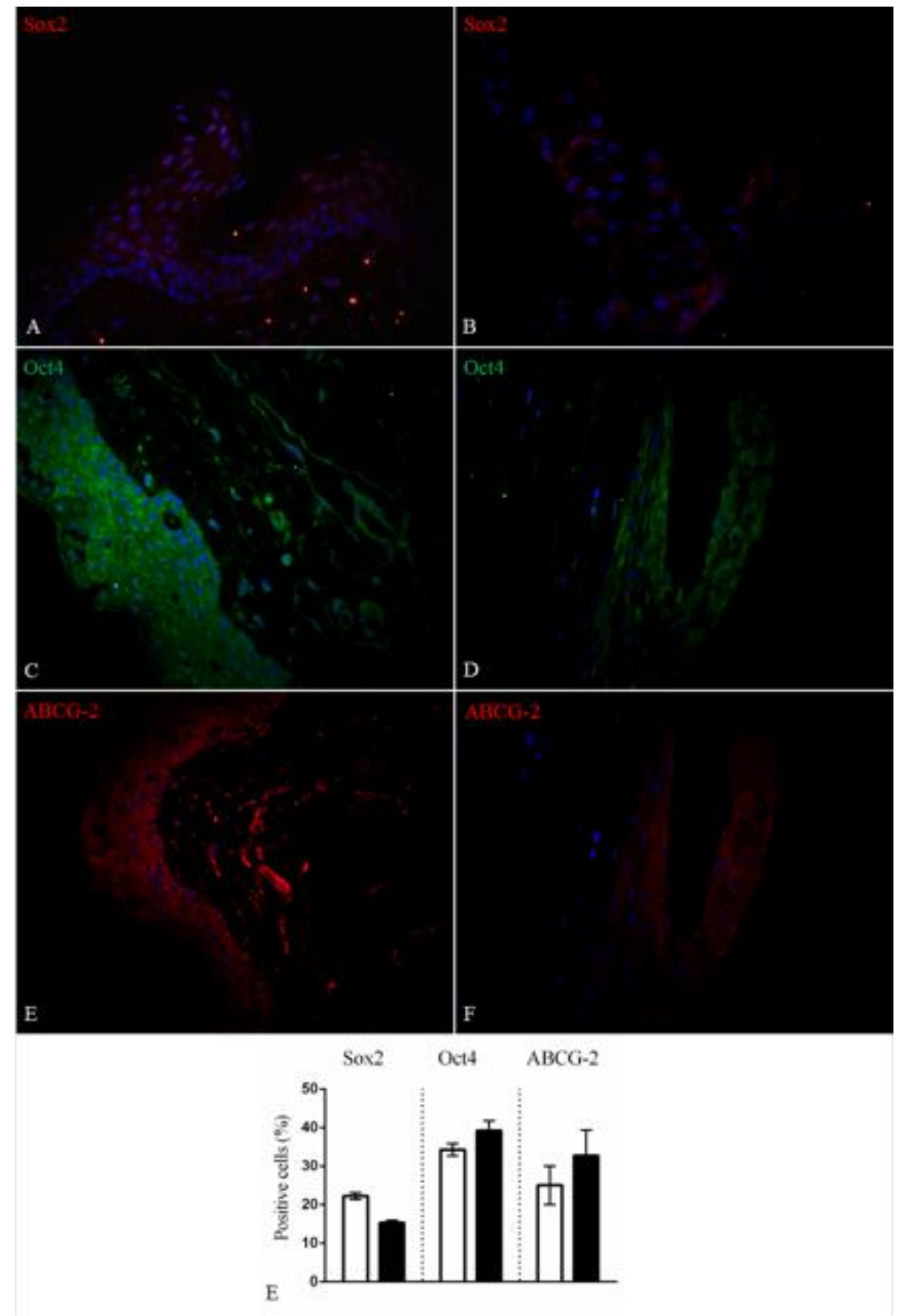

Figure 6. Pterygium tissue and 3D outgrowing cells stained for markers of stemness. Pterygium tissue-containing cultures (A, C and E), and outgrowing cells forming 3D structures (B, D and F) were stained for Sox2, Oct4 and ABCG-2, respectively (Magnification: 40x). White bar represents data from pterygium tissue, while the black bar 
shows results from independently grown 3D outgrowing cells. Data are expressed as mean \pm SD.

Oxidative stress markers $(8-\mathrm{OHdG}$ and HIF-1 $\alpha$ ) were determined in the pterygium graft tissue $(42.4 \pm 3 \%$ and $13.8 \pm 2.3 \%)$, respectively and in the multi-layered outgrowing cells $(62.3 \pm 8.6 \%$ and 26.6 $\pm 4.8 \%$ ), respectively (Fig. 7). The expression of migration and proliferation markers (CXCR4 and Ki-67), was $(27.2 \pm 4.5 \%$ and $5.1 \pm 0.4 \%$ ), respectively, in the pterygium graft tissue, and $(67.3 \pm 4.7 \%$ and $1.2 \pm 0.3 \%)$, respectively, in the multi-layered outgrowing cells (Fig. 8).

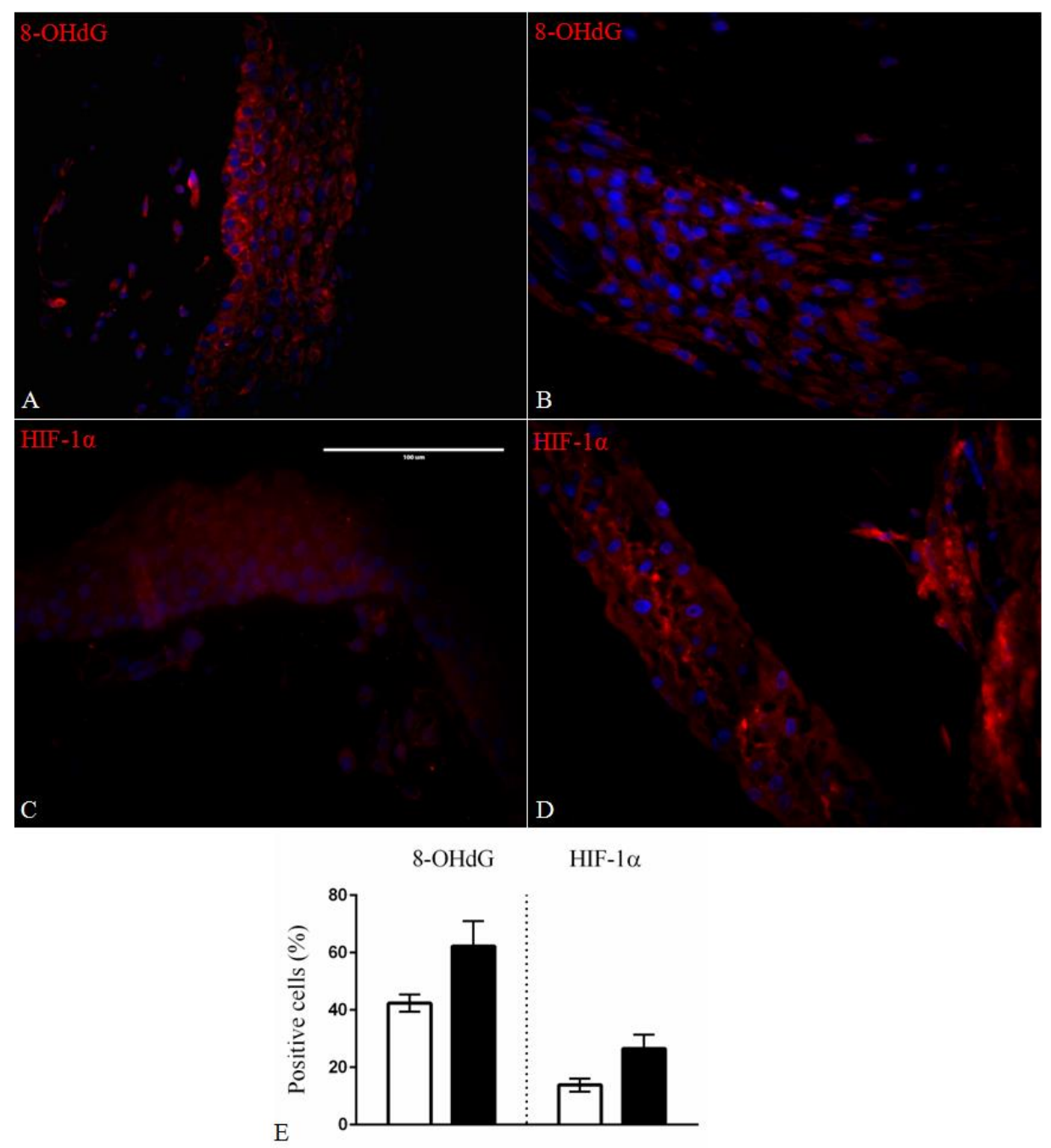

Figure 7. Pterygium tissue and 3D outgrowing cells stained for oxidative stress markers. Pterygium tissue-containing cultures $(\mathrm{A}, \mathrm{C})$, and outgrowing cells forming 3D structures (B, D) were stained for $8-\mathrm{OHdG}$ and HIF-1 $\alpha$, respectively (Magnification: 40x). White bar represents data from pterygium tissue, while the black bar shows results from independently grown 3D outgrowing cells. Data are expressed as mean \pm SD. 


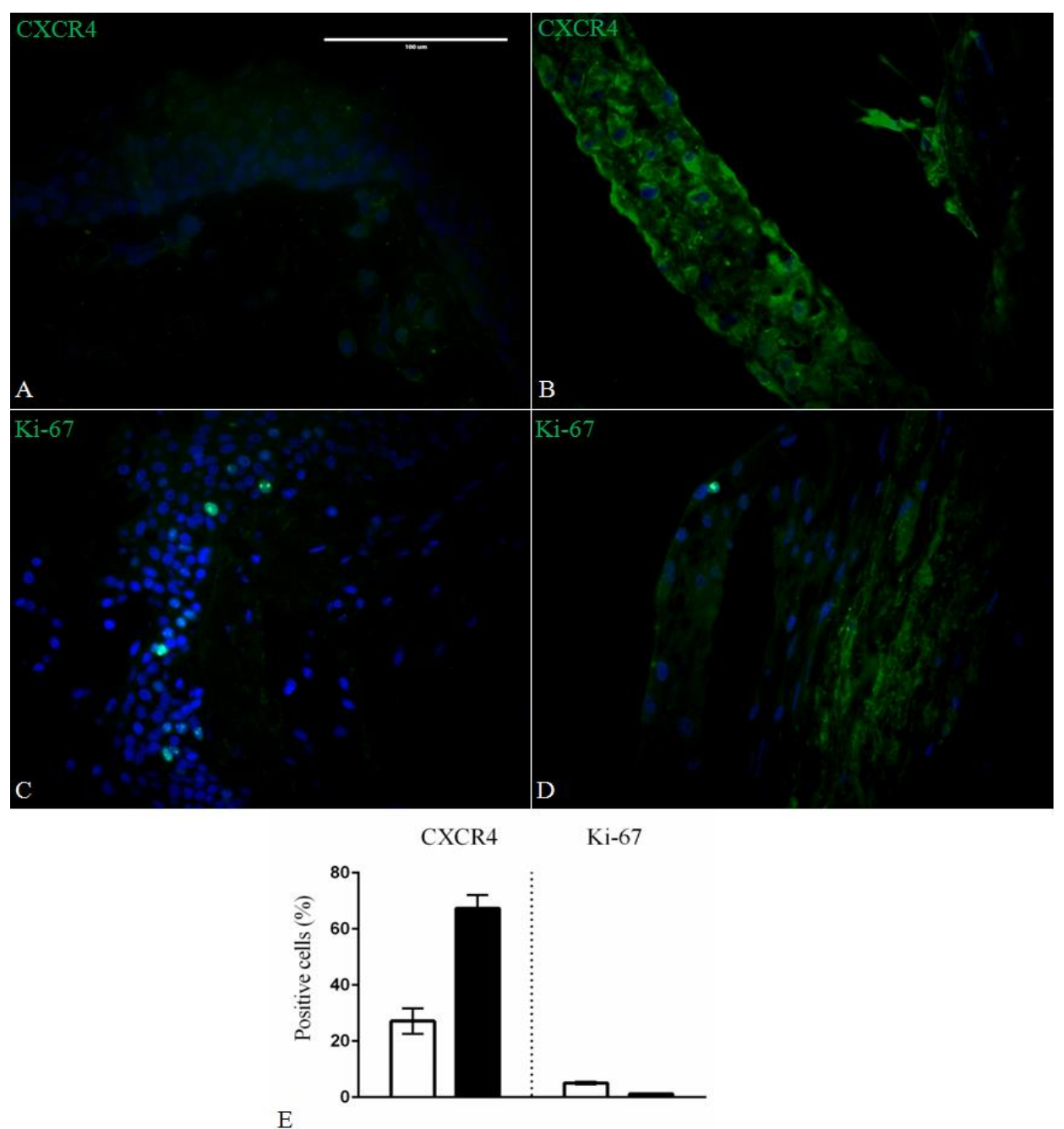

Figure 8. Pterygium tissue and 3D outgrowing cells stained for migration and proliferation markers. Pterygium tissue-containing cultures (A, C), and outgrowing cells forming 3D structures (B, D) were stained for CXCR4 and Ki-67, respectively (Magnification: 40x). White bar represents data from pterygium tissue, while the black bar shows results from independently grown 3D outgrowing cells. Data are expressed as mean \pm SD.

The epithelial cell markers expression (CK19 and CK8-18) was (0\% and 24.3 $\pm 6.5 \%$ ), respectively, for the pterygium graft tissue, and $(11.9 \pm 3.7 \%$ and $0 \%)$, respectively, for the multi-layered outgrowing cells (Fig. 9), while that for the secretory markers (MUC1 and MUC4) was (13.1 $\pm 4.3 \%$ and $32.2 \pm 3.3 \%)$, respectively, for the pterygium graft tissue, and $(63.7 \pm 5.7 \%$ and $55.3 \pm 5 \%)$, respectively, for the multi-layered outgrowing cells (Fig. 10). Expression of all markers in \% is summarized in (Table 4). 


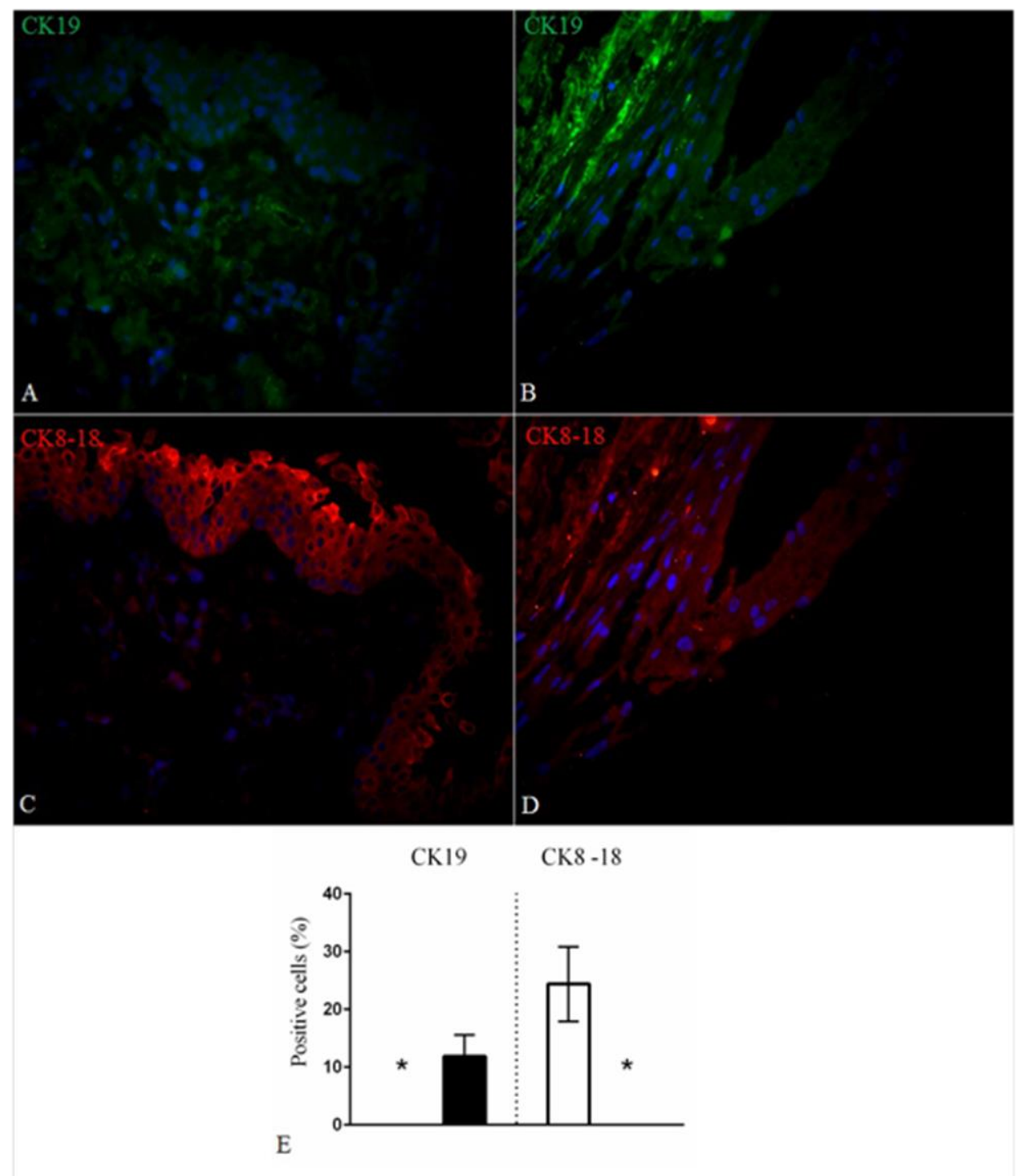

Figure 9. Pterygium tissue and 3D outgrowing cells stained for epithelial cell markers. Pterygium tissue-containing cultures (A, C), and outgrowing cells forming 3D structures (B, D) were stained for CK19 and CK8-18, respectively (Magnification: 40x). White bar represents data from pterygium tissue, while the black bar shows results from independently grown 3D outgrowing cells. Data are expressed as mean \pm SD. 


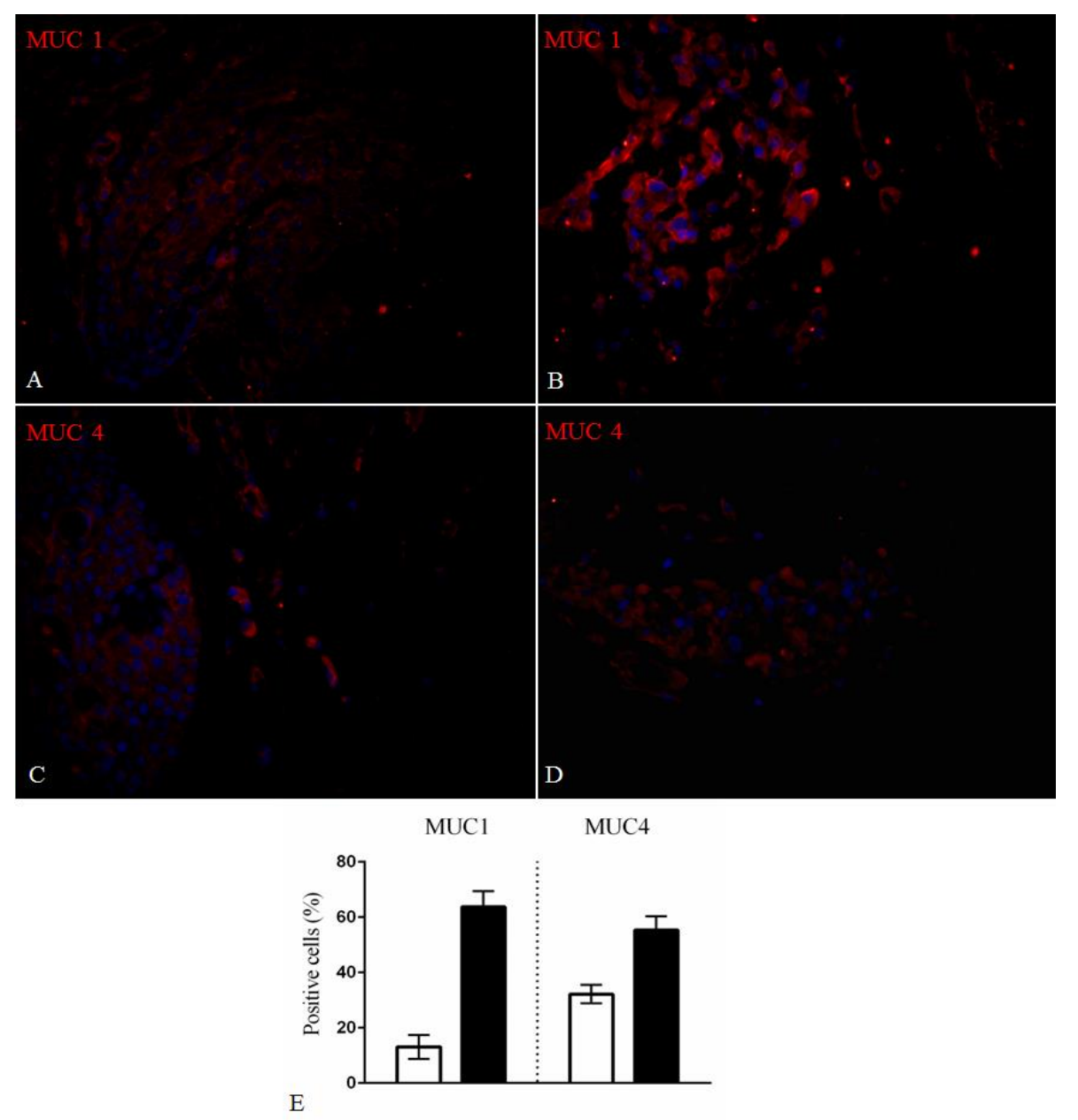

Figure 10. Pterygium tissue and 3D outgrowing cells stained for secretory markers. Pterygium tissue-containing cultures (A, C), and outgrowing cells forming 3D structures (B, D) were stained for MUC1 and MUC4, respectively (Magnification: 40x). White bar represents data from pterygium tissue, while the black bar shows results from independently grown 3D outgrowing cells. Data are expressed as mean \pm SD. 
Table 4. Expression of a wide range of markers from immunofluorescent staining examined in the pterygium grafts obtained directly from surgery and compared to those from long-term cultivated 3D outgrowths from the pterygia shown in \%.

\begin{tabular}{|c|c|c|c|}
\hline & & Pterygium graft & $\begin{array}{c}\text { Multi-layered outgrowing } \\
\text { pterygium cells }\end{array}$ \\
\hline \multirow[t]{2}{*}{ Pluripotency markers } & Vim & $26.5 \pm 3.5 \%$ & $43.7 \pm 4 \%$ \\
\hline & $\Delta \mathrm{Np} 63$ & $13.9 \pm 0.9 \%$ & $12.3 \pm 1.5 \%$ \\
\hline \multirow[t]{3}{*}{ Stemness markers } & Sox 2 & $22.2 \pm 0.9 \%$ & $15.3 \pm 0.6 \%$ \\
\hline & Oct4 & $34.2 \pm 1.6 \%$ & $39.2 \pm 2.5 \%$ \\
\hline & ABCG-2 & $25 \pm 5 \%$ & $32.7 \pm 6.6 \%$ \\
\hline Oxidative stress & OHdG & $42.4 \pm 3 \%$ & $62.3 \pm 8.6 \%$ \\
\hline and hypoxia markers & HIF-1 $1 \alpha$ & $13.8 \pm 2.3 \%$ & $26.6 \pm 4.8 \%$ \\
\hline Migration and & CXCR4 & $27.2 \pm 4.5 \%$ & $67.3 \pm 4.7 \%$ \\
\hline proliferation markers & $\mathrm{Ki}-67$ & $5.1 \pm 0.4 \%$ & $1.2 \pm 0.3 \%$ \\
\hline \multirow[t]{2}{*}{ Epithelial cell markers } & CK19 & $0 \%$ & $11.9 \pm 3.7 \%$ \\
\hline & CK8-18 & $24.3 \pm 6.5 \%$ & $0 \%$ \\
\hline \multirow[t]{2}{*}{ Secretory markers } & MUC1 & $13.1 \pm 4.3 \%$ & $63.7 \pm 5.7 \%$ \\
\hline & MUC4 & $32.2 \pm 3.3 \%$ & $55.3 \pm 5 \%$ \\
\hline
\end{tabular}




\subsubsection{ELISA measurement of proinflammatory cytokines IL-6 and 8 secreted from 3D outgrowing pterygium cells}

The multi-layered outgrowing cells from the pterygium biopsies secreted moderate and low levels of the proinflammatory cytokine IL-6 and IL-8, respectively, which levels were significantly decreased upon treatment with the antiproliferative agent MMC, in contrast to the level secreted by LESCs (control) for IL-6 ( $\mathrm{p}<0.05)$. The IL-8 secretion upon MMC treatment did not change significantly although was lower than that secreted by LESCs (Fig. 11, A, B). Both, the inflammatory cytokines' release and the treatment by MMC have clinical relevance in case of recurrent pterygia.

IL-6

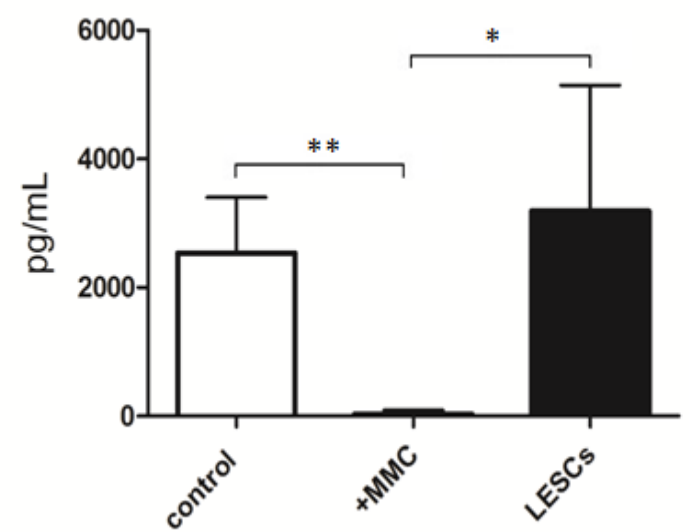

IL-8

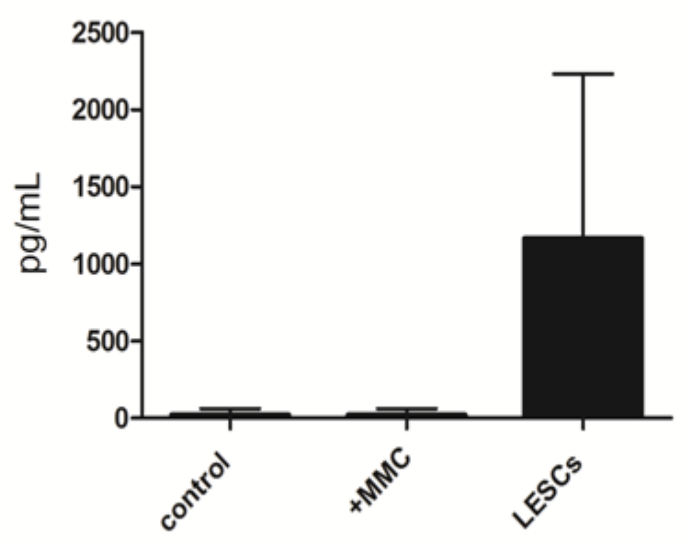

B

A

Figure 11. Cytokine secretion by 3D outgrowing cells from pterygium tissue grown $e x$ vivo. Treatment by Mitomycin C (MMC) and limbal epithelial stem cells (LESCs) is shown for comparison. The significant data for secretion of IL-6 is presented with asterisk (*) while IL-8 did not show a significant expression. 


\subsubsection{Human eye explant tissues adhere to the cell culture dish under a gravitational force of viscoelastic material}

Novel, simple, and reproducible method for ex vivo cultivation of human explant tissues (aLCs and fvERMs) was established using viscoelastic material (Fig. 12).

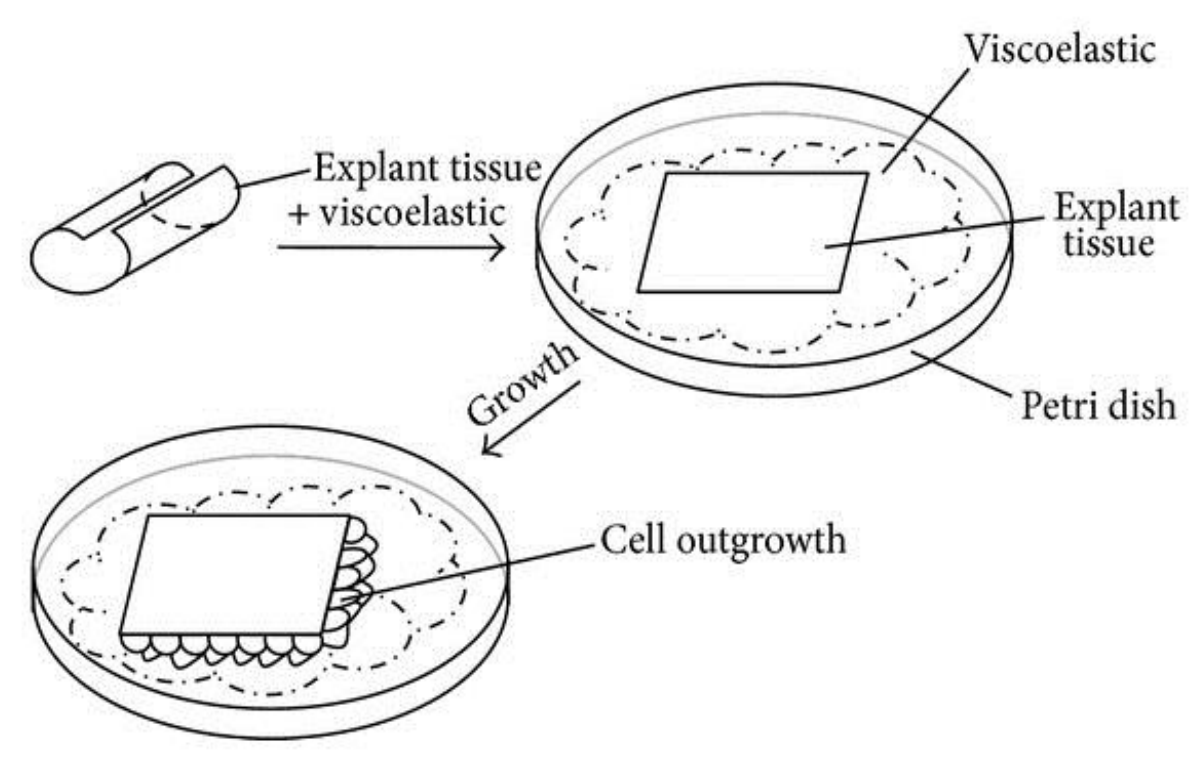

Figure 12. Method for adherent ex vivo cultivation of human eye tissue explants in a cell culture Petri dish.

The cells started proliferating out of the explants in 2-3 days (Fig 13). The method for attachment of human eye tissue explants to the 12-well plates is shown in Fig 13(a) - the aLC explant and the cells are flattened under the gravitational force of the viscoelastic material. The fvERM cells grew out of the explants within 24 hours and continued proliferating independently throughout the study period (for more than 6 months) (Fig 13(b)). 


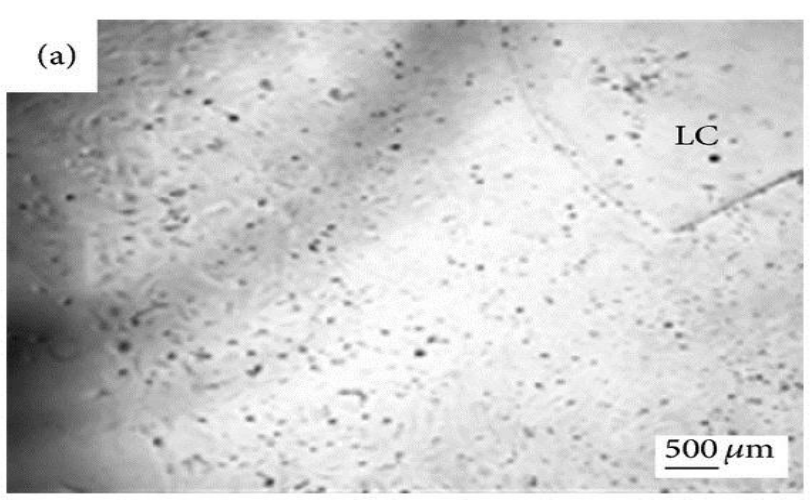

(b)
Figure 13. Examples of attached human eye explants with the growing cells: (a) anterior lens capsule (aLC) in a 12-well plate; (b) fibrovascular epiretinal membrane (fvERM) cells growing attached to and independently from the tissue explant in a cell culture Petri dish.

\subsubsection{Mechanical stimulation and $\mathrm{ACh}$ induce rise in $\left[\mathrm{Ca}^{2+}\right]$ in the aLC-LECs}

The functionality of the aLC-LECs attached under the viscoelastic was examined during mechanical stimulation and application of agonist $\mathrm{ACh}$, both of which induced rise in the $\left[\mathrm{Ca}^{2+}\right]_{\mathrm{i}}$. Representative examples of 6 explant cultures were analyzed for mechanical stimulation containing 27 cells being stimulated (mostly the cells on the glass surface and some on the aLC); similarly, representative examples of 5 explant cultures were analyzed for ACh stimulation. (Fig 14) shows the calcium signaling upon agonist ACh stimulation of the aLC explant-cultured cells. The oscillations of $\left[\mathrm{Ca}^{2+}\right]_{i}$ are clearly visible here, with each cell having its own frequency of oscillation (Fig 14(b), upper part): 50 cells were analyzed here, out of which $15(30 \%)$ had oscillating response with average of $16.6 \pm 4.4 \mathrm{sec}$ from minimum to minimum. Accommodation can be observed for the green trace as the interval between the two maxima decreases with time, while a time delay of 2-3 sec in the $\left[\mathrm{Ca}^{2+}\right]_{i}$ propagation can be seen (Fig 14(b), lower part) needed for the $\left[\mathrm{Ca}^{2+}\right]_{i}$ to reach its first maximum for different ROIs of the same cell (blue and red). No mechanically stimulated cell responded at oscillation manner. The transient responses to mechanical stimulation were usually comparable to those elicited by ACh. 


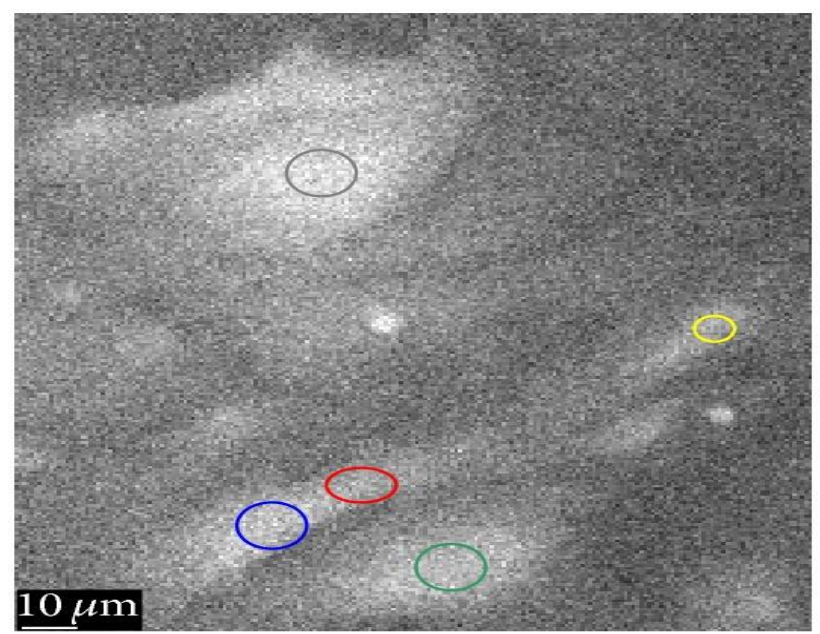

( a )

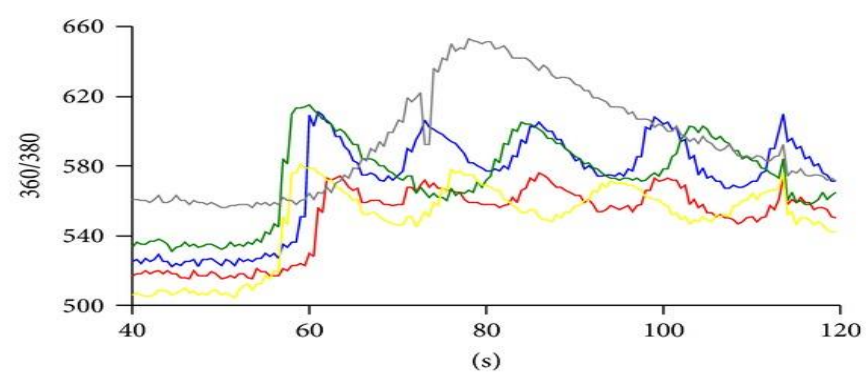

(b )

Figure 14. Calcium signaling upon agonist ACh stimulation of the aLC explant-cultured cells (a). The traces (b) represent the time courses of the 360/380 ratio $(R)$, proportional to $\left[\mathrm{Ca}^{2+}\right]_{\mathrm{i}}$ and correspond to the regions of interest (ROI) shown on the $\mathrm{B} \& \mathrm{~W}$ image (a) in the same colors (explant growth time: 28 days).

The calcium signaling upon mechanical stimulation of a single cell of the aLC explant culture showed $\left[\mathrm{Ca}^{2+}\right]_{i}$ propagation as well (Fig. 15) - in the example shown, 2/6 cells had response with two peaks, the first one being bigger than the other and the time interval between the peak maxima being 25 and $26 \mathrm{sec}$; the rest of the cells had no or very small calcium increase. The blue ROI represents the stimulation site and the red ROI represents the more distal site. There is a delay of around $5 \mathrm{sec}$ in the time needed for the $\left[\mathrm{Ca}^{2+}\right]_{\mathrm{i}}$ to reach its maximum at two selected ROIs. The increases in $\left[\mathrm{Ca}^{2+}\right]_{\mathrm{i}}$ in the cells surrounding the mechanically stimulated cell suggest the involvement of intercellular connections. 


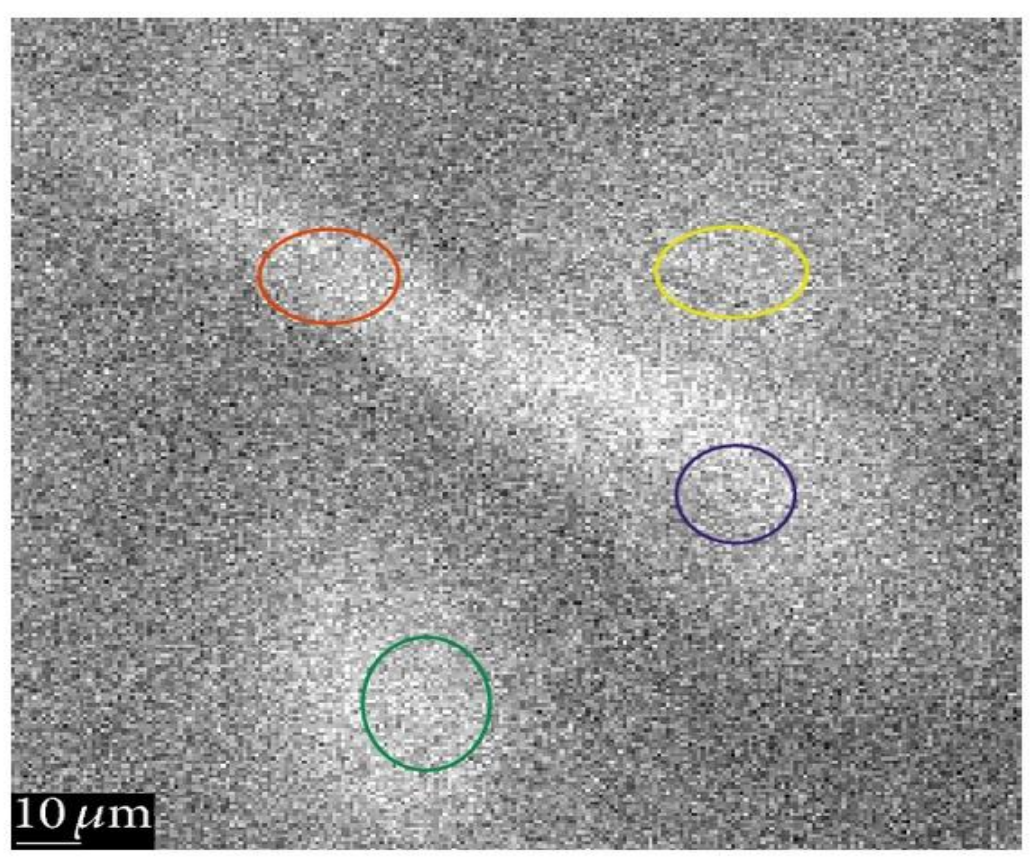

(a)

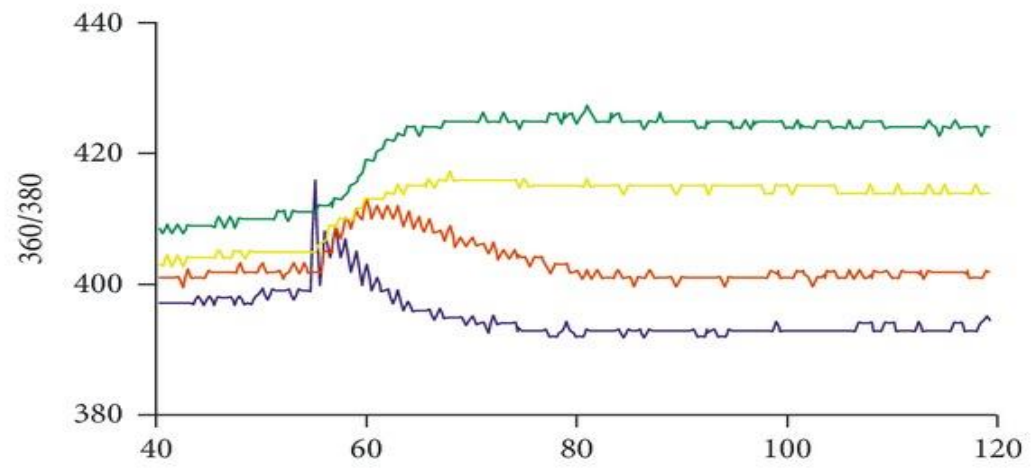

(s)

(b)
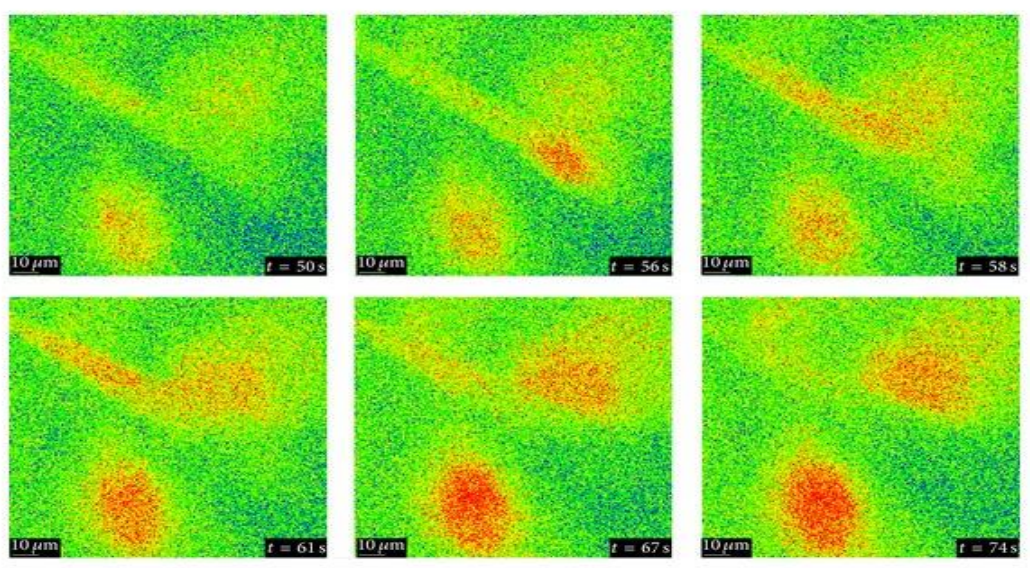

(c)
Figure 15. Calcium signaling upon mechanical stimulation of a single cell of the aLC explant culture, showing the $\left[\mathrm{Ca}^{2+}\right]_{i}$ propagation and involvement of intercellular connections. The traces (b) represent the time courses of the 360/380 ratio $(R)$, proportional to $\left[\mathrm{Ca}^{2+}\right]_{\mathrm{i}}$ and correspond to the regions of interest (ROI) shown in the $\mathrm{B} \& \mathrm{~W}$ image (a) in the same colors. (c) A series of the $360 / 380$ ratio images at the time points are indicated. The values for $\mathrm{R}$ are color coded with blue/green representing low ratio values and yellow/red representing high ratios (explant growth time: 14 days). 
The intercellular dendrite connection strength upon mechanical fluid movement for the nonattached dendrites in aLC explant culture could also be observed (Fig. 16). Indeed, a confirmation that the $\left[\mathrm{Ca}^{2+}\right]_{i}$ changes are not dependent on the mechanical effect of fluid movement but on $\mathrm{ACh}$ is shown by the

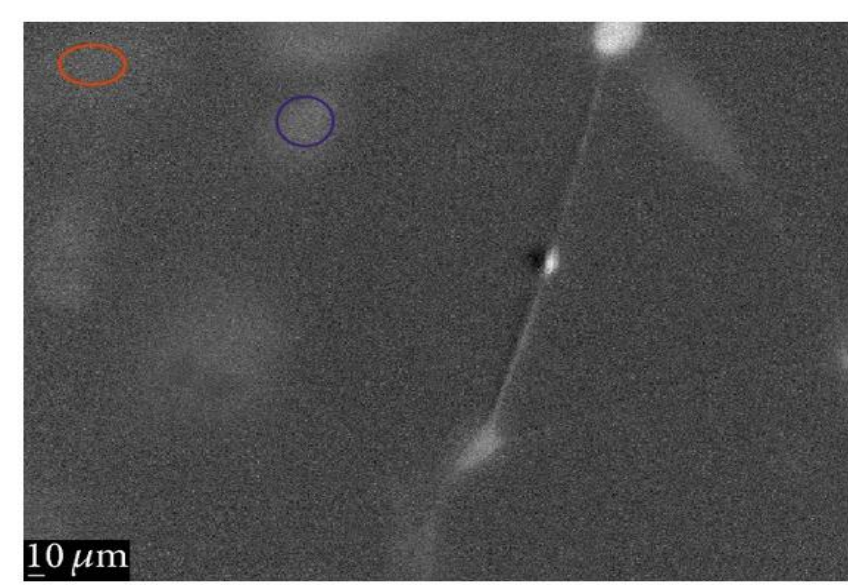

( a )

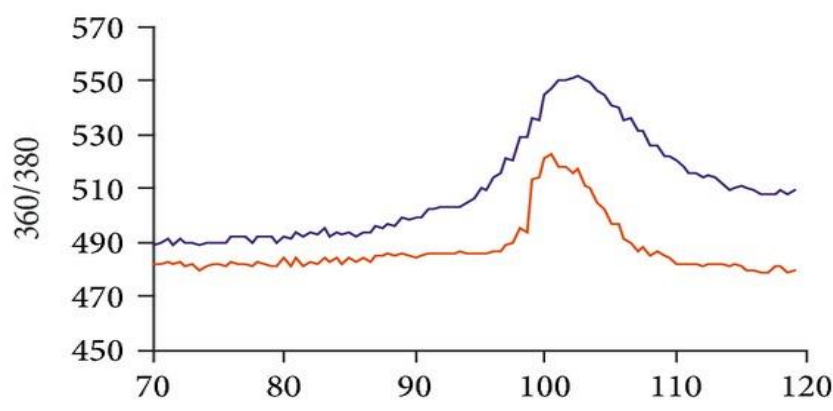

(s)

( b )
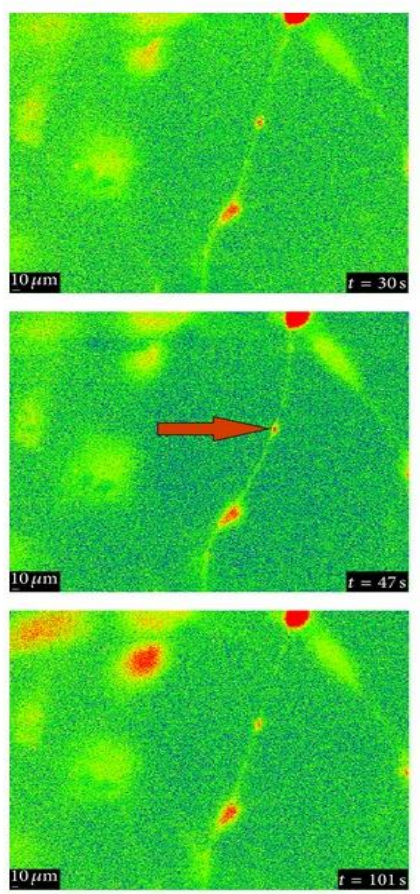
fact that $\left[\mathrm{Ca}^{2+}\right]_{\mathrm{i}}$ increase occurs much later $(t=101 \mathrm{~s})$ in comparison to the dendritic movement dependent on the mechanical effect of fluid movement $(t=39-47 \mathrm{~s})$ as visible on Fig 16(c).

Figure 16. The intercellular dendrite connection strength upon mechanical fluid movement for the nonattached dendrites in aLC explant cultures. The traces (b) represent the time courses of the $360 / 380$ ratio $(R)$, proportional to $\left[\mathrm{Ca}^{2+}\right]_{\mathrm{i}}$ and correspond to the regions of interest (ROI) shown in the $\mathrm{B} \& \mathrm{~W}$ image (a) in the same colors. (c) A series of the 360/380 ratio images at the time points are indicated. The values for $R$ are color coded with blue/green representing low ratio values and yellow/red representing high ratios (explant growth time: 21 days).

The $\left[\mathrm{Ca}^{2+}\right]_{\mathrm{i}}$ dynamics upon mechanical stimulation of fvERMs has been previously described by our group (14) which is a proof of the viability and functionality of these cells.

(c) 


\subsubsection{Measurement of proinflammatory/angiogenic factors secreted by the fvERM and aLC-LECs outgrowing cells upon TNF $\alpha$ treatment}

The outgrowing cells from the fvERMs showed basal expression of the proinflammatory cytokine IL-6 ex vivo, which was further enhanced by TNF $\alpha$ stimulation. Similar enhancement was noted in the proinflammatory cytokine release of IL-8 upon TNF $\alpha$ stimulation (Fig 17(a)). In the case of aLC-LECs, there was only IL-6 TNF $\alpha$-induced secretion (Fig 17(b)).
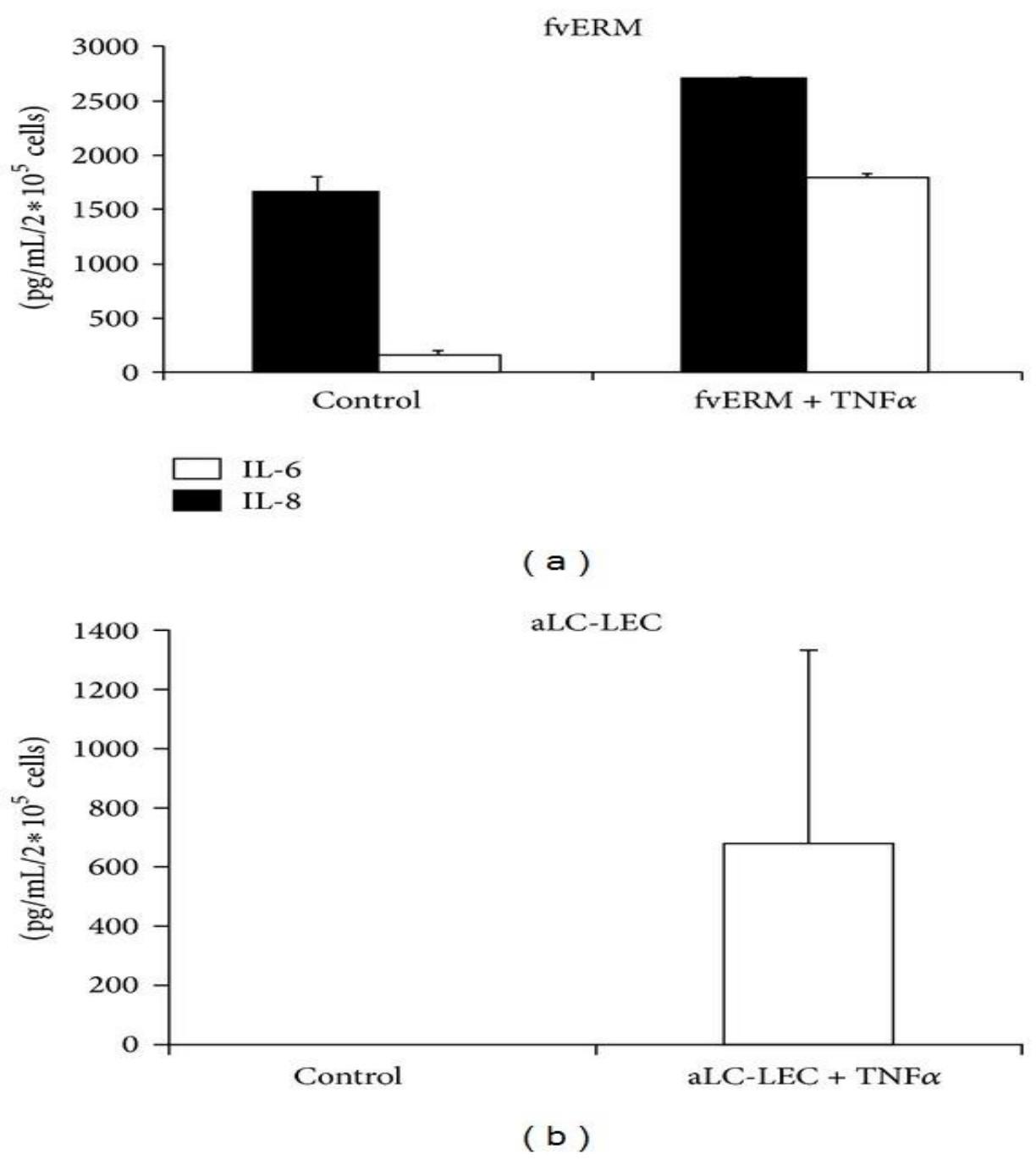

Figure 17. Cytokine secretion by fvERM and aLC-LEC outgrowing cells upon TNF $\alpha$ treatment. 


\section{Discussion}

The anterior segment of the eye ball, which serves as the barrier to the external stimuli includes the transparent cornea - a "window" for the light sensor; the conjunctiva, which covers the sclera - the main part of the eyeshell; and the lens (15). We aimed to adherently cultivate ex vivo cultures from three different types of tissue from three different types of pathologies in the eye: 1) pterygium, 2) aLCs containing LECs from cataract surgery, and 3) fvERMs from vitrectomy for proliferative diabetic retinopathy (PDR), and to let them form $2 \mathrm{D}$ and/or 3D structures. Furthermore, we aimed to characterize the obtained cells and treat them accordingly so that different markers can be measured, including IL-6 and IL-8 (markers for inflammation/angiogenesis).

Pterygium is a disease of the ocular surface that is associated with chronic UV exposure and is characterized by proliferation, inflammatory infiltrates, fibrosis, angiogenesis and extracellular matrix breakdown. Centripetal growth connected with inflammation and neovascularization is characteristic for the condition. Pterygium is not fully understood and significant progress has been made toward understanding the mechanisms involved in its pathogenesis $(16)(17,18)$.

Many factors are included in the etiology of the disease, thus making it not just a degenerative, but also a proliferative disorder of the ocular surface supported by abnormal expression of p53 in the epithelium of pterygium tissue. The environmental factors such as exposure to sunlight and UV-B light seem to be among the most important risk factors, although genetics may also contribute to the pterygium development (19). Apart from ultraviolet and infrared radiation from sunlight, many other factors can predispose to pterygium, including environmental irritants such as wind, dust, trauma, inflammation, as well as an increased incidence is noted in certain occupations, such as welding, landscaping, farming, and fishing. Pterygia are more commonly seen in individuals from warmer climates secondary to higher amounts of time spent outdoors, and are twice likely to occur in men than women (6). Based on some studies, limbal stem cell deficiency has also been involved in pterygium development. There are several theories on the pathogenesis of pterygium: one states pterygium to be derived from a pingueleculum, which is a yellowish growth on the corneal limbus, while another supposes chronic infection and thrombosis of the conjunctival veins to be the cause. However, these theories do not provide a good explanation for the wing-like shape and location of pterygia. Some findings show that pterygium may be due to 
invasion of the cornea by subconjunctival fibroblasts or there may be a pterygium angiogenesis factor that attracts blood vessels onto the cornea. An immunologic mechanism may also contribute to the development of pterygium, due to infiltration of small lymphocytes and plasma cells into its core $(6,20)$.

Pterygium as a structure consists of a mixture of epithelial and fibroblastic cells, proliferation of which closely determines its recurrence and severity (3). The stratified outgrowing cell model for pterygium expansion ex vivo described by our group has the advantage of giving immediate adherence of the graft to the cell culture plate (e.g. using viscoelastic material), therefore, providing both cell types an equal chance to expand, without the use of any growth factors. The outgrowing cells expressed CK8-18 - a typical epithelial cell marker, also expressed by other human corneal cells such as epithelial and endothelial cells $(21,22)$, as well as the LESC marker CK19 $(23,24)$.

Recently, it has been shown that pterygium growth and development are connected with proliferation of the epithelium as well as the fibrovascular layer. It is thus believed that pterygium is formed from an uncontrolled cell proliferation. Two markers: the proliferating cell nuclear antigen (PCNA), a cofactor for DNA polymerase $\delta$ in both S phase and during DNA synthesis associated with DNA damage-repair mechanisms, and Ki-67, have been studied previously and found to be more highly expressed in pterygium cells compared to normal conjunctiva (25). Ki-67 is also expressed in conjunctival and eyelid tumours (26), the positivity of which appeared to be low in our pterygium graft-containing cultures, and was additionally five times less expressed in the multi-layered outgrowing tissue. The SDF1/CXCR4 signalling pathway has been described in the developmental processes and adult angiogenesis to have a role in vascular endothelial cell migration and proliferation (27). LESCs themselves possess migratory capacity or positivity for CXCR4 (23), while this marker is expressed by vascular endothelial cells in proliferative diabetic retinopathy membranes as well (28). The pterygium graft-containing cultures showed 2.5 times less positivity for CXCR4 compared to the multi-layered outgrowing cell cultures.

Vimentin is a cytoskeletal intermediate filament and part of the Epithelial-Mesenchymal Transition (EMT), which converts epithelial cells into mesenchymal-like derivatives. Some evidence suggests that Vim filaments take a role during cell motility, spreading and signalling. Expression of Vim has been found in epithelial cells at the edges of healing wounds in corneal epithelium and in cells at the limbal epithelium. Vim can be considered 
important for migration and proliferation of stem cells and epithelial progenitors during their centripetal movement into central cornea and through wound closure (29). Vim was indeed found to be highly expressed by our pterygium-graft containing and the multilayered/stratified outgrowing cells.

Similarly, $\Delta$ Np63 was expressed at a steady and comparable extent in both cell cultures, the protein being known for its role in activation or inhibition of apoptosis in a cell- and tissuetype specific manner. $\Delta \mathrm{Np} 63 \alpha$ is the most present isoform in the central corneal epithelium, which seems to be lost during apoptotic cell death in the corneal epithelium (30). $\Delta \mathrm{Np} 63$ is also important in the regulation of LECS proliferation and its expression in the limbal epithelium plays role in the homeostasis of limbocorneal epithelium in rabbit limbal epithelial cells (31).

UV-B radiation is known to cause oxidative DNA damage and is thought to be a major factor implicated in the pathogenesis of pterygium, playing an important role in its reccurence as well. Because of that, it is important to maintain proper antioxidant defense in patients after surgery of primary pterygium $(32,33)$. The molecule $8-\mathrm{OHdG}$ - a ubiquitous marker of oxidative stress which possesses high mutagenic potential, mispairs with adenine during DNA replication, resulting in $\mathrm{G}: \mathrm{C}$ to $\mathrm{T}: \mathrm{A}$ transversion mutations - has been established to be a sensitive marker of oxidative DNA damage (33). It has been found to be expressed more in the epithelium of the head of primary pterygium compared to healthy conjunctiva. While pterygium is considered to be a non-metastatic lesion with limited local invasion, the presence of $8-\mathrm{OHdG}$ could confirm visible genetic instability, which is in contrast to its benign clinical course. It has been shown that UV-B and inflammatory mediators as well have impact on the ECM remodelling through increased expression of matrix metalloproteinases including MMP1 (collagenase), MMP-2 (gelatinase A), MMP-3 (stromelysin 1), MMP-7 (matrilysin), of MMP-8 (neutrophil collagenase), MMP-9 (gelatinase B) and membrane-type MMP (MMP-14 and MMP-15). All of these factors may contribute to limbal degeneration and subsequent pterygia formation $(3,17,34)$. In our model, high expression of $8-\mathrm{OHdG}$ was found in the pterygium graft itself, which was further increased in the outgrowing cells.

Hypoxia inducible factor HIF-1 $\alpha$ plays an important role in the modulation of cell metabolism and survival pathways, as well as couples with stem-cell-like properties in cells containing elevated expression of this marker. There is a coordinated activation of HIF-1 $\alpha$ and heat 
shock proteins in pterygium and the upregulation of the same may represent adaptive process for the survival of cells under stressful conditions (35).

A healthy cornea is maintained by self-renewing, lineage-specific stem cells (SCs) that reside in the limbus. This regenerative capacity is regulated by proliferation, migration, and differentiation of such cells. Failure to maintain a normal microenvironment as a result of extrinsic (e.g. UV radiation) or intrinsic (e.g. cytokines) signals can cause development of ocular disorders such as pterygium (36). The epithelial cells in the pterygium can keep their potential to divide, which supports the view of pterygium as a disease of altered limbal stem cells. There is a possibility that pterygium cells have stem cell origin, which is confirmed by the presence of telomerase activity in pterygial epithelium (37). Although there have been numerous reports on existence of stem cell markers within the eye, no such evidence has been provided for the pterygium cells. Sox 2 has been described as being expressed in many epithelial cell types, including conjunctival epithelial cells. In the epithelial cells of the conjunctival ocular surface, but not the stromal cells, another pluripotent stem cell marker Oct4, has been found expressed (38). ABCG-2 has a role in the maintenance of retinal stem cells under the regulation of Notch signalling. The expression of ABCG-2 in canine limbal epithelial cells has been considered a useful marker for presence of putative corneal epithelial stem cells and proliferation $(39,40)$. The ex vivo 3D tissue engineered pterygium outgrowths and the graft-containing cultures expressed all of these stem cell markers (Sox2, Oct4 and ABCG-2).

Oxidative stress caused by sunlight can induce growth factor production, angiogenesis, chronic inflammation and collagenolysis. After sunlight triggers pterygium onset, the proliferating fibroblasts can generate reactive oxygen species (ROS), through which sustained inflammation can occur (41). UV light can activate epithelial cells which are near the limbus to produce cytokines such as IL-6 and IL-8, so they can mediate inflammation, proliferation, angiogenesis and anti-apoptosis. IL-8 is a product of activated monocytes and fibroblasts, and of endothelial and epithelial cells, while IL-6 is synthesized by various cells, such as fibroblasts, endothelial cells, and keratinocytes, in response to numerous cytokines including TNF- $\alpha$ and IL-1. Interleukins 1, 6 and 8 are all increased in pterygia after UV-B exposure, which contributes to upregulation of other inflammatory mediators and matrix metalloproteinases and potentially to pathogenesis of the disorder. Similarly, other inflammatory mediators like cyclooxygenase- 2 and phospholipase $\mathrm{D}$, have also been found in pterygia. Elevation of inflammatory mediators here is, however, likely a secondary process 
(17). It has been found that growth factors with potent angiogenic activity, such as FGF, PDGF, TGF $\beta$ and TNF can be secreted from fibroblastic and inflammatory pterygium cells as well as in tissue cultures from pterygium fibroblasts; it was thereby suggested that various cytokines and growth factors including VEGF, can attribute to cellular proliferation, inflammatory reaction, remodelling of ECM and angiogenesis of pterygium (42). Indeed, an abundant immunoreactivity for IL-6 and IL-8 has been found in pterygial epithelium (43), while our 3D pterygium outgrowing cells showed only a high expression of IL-6.

Conjunctival autografts, amniotic membrane transplantation and treatment with radiation or chemotherapeutic agents, usually MMC, are often used to reduce recurrence of pterygium (8). MMC is an antibiotic-antineoplastic agent that selectively inhibits the synthesis of DNA, cellular RNA and protein. It is widely accepted to be effective in preventing recurrence of excised pterygium (44). The optimal dosage of MMC for pterygium surgery is still unknown, however, extreme caution in its use is required due to its toxicity. The lowest possible concentration should be applied for the shortest time period to avoid complications (45) (46). In our experiments, MMC reduced the level of secreted cytokines (in particular IL-6), which provides a combined anti-inflammatory and anti-proliferative therapy for pterygium at a cellular and molecular level.

A positive clinical correlation has been found between pterygium and dry eye in some studies, and an unstable tear film has been proposed to contribute to the pathogenesis of pterygium. It is possible that the presence of an elevated tissue, like pterygium, poses a problem for tears to cover the ocular surface, resulting in localized areas of dryness.

A connection between squamous metaplasia of the conjunctival epithelium and goblet cell density has been described. Positive mucin granules have been found on the surface of pterygium, indicating an increased goblet cell density over the pterygium surface. This unique cytologic feature of pterygium further supports the theory of altered epithelial differentiation in the pathogenesis of the disorder (47).

Mucins are large glycoproteins expressed by epithelial cells of both conjunctiva and cornea, and are thought to play an important role in determining the interactions between the cornea/conjunctiva and the overlying tear film (48). Mucins form a hydrophilic barrier for protection and lubrication of the eye. This barrier, the glycocalyx, is formed by MUC1, MUC4, and MUC16 (49). The expression of MUC1 and 4 in our pterygium graft-containing 
cultures and the stratified outgrowing cells was clearly high, probably making our ex vivo model for pterygium being close to the model of a goblet cell hyperplasia.

The pterygium outgrowing cells were still viable after having undergone more than three months cultivation time, which was further confirmed by the high expression of CD47 at the ending check point. The surface marker profile of ex vivo cultivated outgrowing cells showed CD44, a protein expressed actively on dividing cells (50), to be moderately expressed in the stratified outgrowing cells. The expression of ECM attachment proteins, which is vital for the maintenance of cellular growth within the pterygium, was low (CD146/MCAM, CD112/Nectin-2) and moderate (CD166/ALCAM, CD44/H-CAM). Those markers could also be found in LESCs, while the expression of CD73 and CD105 in the 3D outgrowing cells from pterygium was in general lower than that found in LESCs (23). Expression of CD105 has been described previously to have a role in neovascular endothelial cells formation in the subepithelial area of primary pterygia, while a correlation between the expression of VEGF in the stroma and CD105-MVD in primary pterygia has also been proposed. Overexpression of VEGF and CD105-MVD can contribute to pterygium progression by increasing angiogenesis and growth (51). Another important cell source for the formation and recurrence of pterygium, can be the bone marrow-derived multipotential stem and progenitor cells. Both hematopoietic and mesenchymal stem cells have been proposed to contribute to pterygial fibrovascular stroma supported by the increase in $\mathrm{CD} 34^{+}$progenitor cells in the blood of such patients. It has been proposed, that a pterygium grading system should be based upon the infiltration of stem cells to better predict the risk of recurrence clinically (52). The expression of such hematopoietic cell surface markers CD34 and 'don't eat me' signal CD47 in our 3D outgrowing cell from pterygium cells proved to be low and high, respectively. The population of $3 \mathrm{D}$ outgrowing cells from the pterygium contained a low level of the early progenitor cell marker CD117/c-kit as well.

In the next part of our study, we established a novel method for ex vivo cultivation of pathologic tissues obtained from human eyes during cataract surgery and PDR. Viscoelastic material was used for ex vivo expansion of the outgrowing cells. After forming 2D structures, the cells were exposed to mechanical and ACh stimulation, depicting calcium signaling and presence of ACh receptors on the cells as well, as studies on inflammation. The outgrowing cells, over time, migrated out of the explants and grew adherently onto the surface of the cell culture dish, showing signs of continuous proliferation. 
There are alternative methods for achieving adherence of tissue explants, including the use of dry surface, concentrated serum drop, or the fibrin-glue method - the latter being used mostly for in vivo purposes. However, there is an advantage of using a viscoelastic material, since it can avoid use of extreme conditions such as dryness of the cell culture and serum stimulants, yet preserving natural architecture of the tissue and standard nutritional state of the cells. The viscoelastic is an inert substance having viscous, elastic, and gravitational properties which force the graft to attach to a surface. It is used in ophthalmic surgical procedures to maintain deep anterior chamber, which facilitates manipulation inside the eye with reduced trauma to the corneal endothelium and other ocular tissues.

We used two tissue types to establish adherent ex vivo explant cultures: aLCs containing LECs and fvERMs from PDR. Tissue and cell adherence allowed measurement of the $\left[\mathrm{Ca}^{2+}\right]_{\mathrm{i}}$ upon mechanical or pharmacological stimulation, giving advantage of having less noise from cellular movement within the cell culture dish.

To follow and coordinate the physiological processes occurring among cells in different tissues and organs, studying the intercellular communication is very important. (53). Precise regulation of intracellular calcium levels is crucial to maintain normal cellular function, therefore, fluctuations in the cytosolic calcium can act as a signal for numerous physiological processess. As calcium plays a role in the cell signaling of the lens epithelium, accurate regulation is substantial, indicating that imbalanced levels of it may be a leading cause to the development of cataract in the lens $(47,54,55)$. Although abnormalities in calcium regulation have been implicated in the development of most forms of cataract, the mechanisms by which $\mathrm{Ca}^{2+}$ is regulated in the cells of the ocular lens remains poorly defined. In experimental conditions, applying a mechanical stimulus to a single cell can elicite intercellular $\mathrm{Ca}^{2+}$ waves. Previously, this type of stimulation has been used to induce $\left[\mathrm{Ca}^{2+}\right]_{\mathrm{i}}$ rise in cultured bovine LECs (53). Contractions could also be mechanically induced in human aLECs attached to the surgically isolated capsules. Such stimulation of a single cell within a confluent layer was shown to initiate cell-to-cell calcium signalling (56). Our results show an increase in the $\left[\mathrm{Ca}^{2+}\right]_{i}$ upon mechanical stimulation and application of ACh to aLC-LECs, thus revealing an unique frequency of oscillation by each cell. As we specified before, the increases in $\left[\mathrm{Ca}^{2+}\right]_{i}$ in the cells surrounding the mechanically stimulated cell suggest the involvement of intercellular connections. 
The LECs studied ex vivo showed an increase in $\left[\mathrm{Ca}^{2+}\right]_{\mathrm{i}}$, which similarly suggests existence of intercellular connections. In human aLECs, ACh binds to M1 muscarinic receptors (M1 $\mathrm{mAChR}$ ) and induces a rise in $\left[\mathrm{Ca}^{2+}\right]_{\mathrm{i}}(57-59)$. The origin of $\mathrm{ACh}$ in the lens is not clear; however, its presence can certainly affect cells of the immune system, which possess membrane bound $\mathrm{mAChR}$ and nicotinic $(\mathrm{nAChR})$ receptors that can regulate their function (60-63). Some evidences present that retinal pigment epithelium (RPE) can express nicotinic acetylcholine receptors (nAChRs) as described for other epithelial cells, where nAChRs have been involved in processes such as cell development, cell death, cell migration, and angiogenesis (64).

As lipopolysaccharide (LPS) is a common initiator of inflammation it was shown that inhibition of aldose reductase (AR) prevents LPS-induced inflammatory response in human LECs (58). LPS causes many of the pathologic effects by stimulating host cells to synthesize large quantities of bioactive inflammatory mediators such as nitric oxide, prostaglandins, and cytokines, such as TNF $\alpha$, IL-1, IL-6, and IFN- $\gamma(59,60)$. Cytokines can induce a diversity of host responses that eliminate invading bacteria, when they are at low concentrations; whereas at overwhelming concentrations, they can cause significant morbidity as a result of increased oxidative stress and ROS-mediated increase in nuclear factor kappa-light-chain-enhancer of activated B cells (NF- $\kappa \mathrm{B})$ - a well known inducible transcription factor that can cause inflammatory response which can lead to septic shock marked by high fever $(59,61,62)$. The ocular tissues can be exposed to various cytokines and other proinflammatory markers that are released as a result of injury, infection or disease processes (63-65). The lens can also be exposed to various inflammatory mediators associated with bacterial infections present in the aqueous humor (66-68). It has been shown that incubation of human LECs with cytokines such as TNF $\alpha$ increases the activation of NF- $\mathrm{kB}$ and causes cytotoxicity and apoptosis (69, 70) therefore preventing NF- $\mathrm{B}$ activation by $A R$ inhibitors would be expected to rescue human LECs from cell death (71). Transforming growth factor (TGF)-alpha and TGF-beta (2) mRNA have been found to be synthetized by human cataract LEC in situ and after culturing in vitro, so that the cultured LECs could also synthesize IL-8 mRNA (72). IL-1, IL-6, and basic fibroblast growth factor (b-FGF) may be produced in vivo by residual LECs after cataract surgery, which can cause postoperative inflammation and LEC proliferation. The role of these cytokines synthesized by LECs in vitro may be significantly associated with the proliferative processes affiliated with LECs following cataract surgery, which can lead to inflammation and secondary cataract accordingly (73). Some studies reveal that Terminal 
deoxynucleotidyl transferase (TdT)-mediated dUTP nick-end labeling (TUNEL) staining of LECs in capsulotomy specimens is due to necrotic cell death caused by damage during or soon after cataract surgery (74). Furthermore, it has been revealed that expression of TNF $\alpha$ gene in LECs more extended compared with that of IL-1 $\alpha$ in lens capsule samples from cataract surgery. Active synthesis of TNF $\alpha$ and IL-1 $\alpha$ may therefore have consequences on postoperative inflammation and LEC proliferation (69).

The $\left[\mathrm{Ca}^{2+}\right]_{i}$ dynamics upon mechanical stimulation of fvERMs has been described previously by our group. FvERMs in PDR can raise tractional force upon the retina and eventually lead to retinal detachment. Mechanical stimulation of the cells in the membranes or the retina can result in $\left[\mathrm{Ca}^{2+}\right]_{\mathrm{i}}$ changes in a manner of intercellular waves. Generation of calcium occurs by its release from internal stores. The waves do not evoke changes in the cell membrane potential, but may constitute a pathway for extraneuronal signalling. Proper phenotypization of the cell surface markers of ex vivo cultured cells growing out of human fvERMs from PDR gives uptake into their role and function in immunity. The cell adhesion molecules (CAMs) and integrins profile seem to be meaningful in the cell-based tissue integrity structuring and immune response processes (14).

IL-6, IL-8 and TNF $\alpha$ are well known proinflammatory cytokines secreted by macrophages and neutrophils increased in the vitreous of PDR patients (75-77) giving support to the role of inflammatory cytokines in angiogenesis in PDR (78, 79). Increased secretion of proinflammatory cytokines IL-6 and IL-8 was also measured in our fvERM outgrowing cells upon TNFa stimulation. Understanding their role can provide important diagnostic and therapeutic targets for the treatment and prevention of PDR.

The process of C5a activation leads to release of cytokines, ROS, proteolytic enzymes and other proinflammatory molecules (80). Increased levels of MCP-1, IL-1 $\beta$, IL-6, IL-8, and VEGF under C5a treatment have been revealed from retinal pigment epithelial cells (81-83), indicating a correlation between complement fragment C5a and inflammatory cytokines (84). Other proinflammatory molecules, including the Extracellular High-mobility group box-1 (HMGB1), which plays role in the angiogenesis and MCP-1, and ICAM-1, have also been detected in the vitreous of patients with PDR together with MCP-1, and sICAM-1 (85-93). Similarly, connection between CD200, a novel immunosuppressive molecule that exists as a cell membrane-bound protein, and proinflammatory cytokines has been found. The levels of interleukin family members (IL-8, IL-10, IL-6, and IL-18) are indeed significantly elevated in the vitreous humor from PDR patients, expression of which was positively related with 
CD200. These findings suggest that sCD200-CD200R signaling axis may be a critical player in the pathogenesis and development of PDR (94) .

\section{Conclusion}

We adherently cultivated and expanded cells from different tissues using viscoelastic material as a novel and simple method. Human pterygium explants have been demonstrated to give rise to $3 \mathrm{D}$ outgrowing viable cells that can proliferate and migrate out of the grafts and form a stratified structure very much like the one in vivo. The expanding cells carried proteins related to an undifferentiated state, but also a commitment towards epithelial lineage. Manipulating the cell sheets was similar to handling primary human tissues, presuming a possibility for use in tissue engineering and drug discovery. Intracellular calcium dynamics upon mechanical stimulation, calcium signaling, and intercellular communication upon ACh stimulation was measured in aLCs containing LECs, as well as inflammatory cytokines-release studies were performed on aLCs-LECs and fvERM outgrowing cells. Future studies on cell functionality and homeostasis using calcium imaging and inflammation screening open possibilities for development of pharmacological and cell-based therapies that are attractive approach for treating eye diseases. 


\section{Acknowledgement}

I would like to gratefully acknowledge the guidence, support and encouragement to the many people who so generoulsy contributed to my work presented in this doctoral thesis.

First and foremost, I wish to thank my highly enthusiastic and motivating supervisor, Prof. Goran Petrovski, for the tireless support and many hours spent helping me, and for the very fruitful and insightful discussions during my work. I was very much privileged to learn many things from him; he helped me complete this $\mathrm{PhD}$ work and empowered me with enourmous values towards building my future career.

I take the time to express my gratitude to Professor Andrea Facskó, the Head of the Department of Ophthalmology (University of Szeged) for giving me opportunity to be part of her department of scientific excellence.

The thesis would not have come to successful completion without the help I received from all the past and current members of the department and the Stem Cells and Eye Research Laboratory. Special thanks to Dr. Zoltán Veréb, Dr. Dora Szabó, Richard Nagymihály, Dr. Luna Djirackor, Dr. Mária Szatmári Tóth, Dora Eszes and Dr. Reka Albert who have been very kind enough to extend their help at various phases of this research.

Thanks also goes to Dr. Áron Szabó and Dr. Péter Balázs Kocsis for their friendly advices and precious time spent together during my stay in Hungary.

At the end, I owe much my family far away in Macedonia, who encouraged me and helped at every stage of my personal and academic life. 


\section{References}

1. Agrahari V, Mandal A, Trinh HM, Joseph M, Ray A, Hadji H, et al. A comprehensive insight on ocular pharmacokinetics. Drug Deliv Transl Res.6(6):735-54.

2. Kolb H. Gross Anatomy of the Eye. 1995.

3. Cardenas-Cantu E, Zavala J, Valenzuela J, Valdez-Garcia JE. Molecular Basis of Pterygium Development. Semin Ophthalmol. 2014:1-17.

4. Bowling B. Kanski's Clinical Ophthalmology (A systematic approach). 8th ed: Elsevier; 2016.

5. Gebhardt M, Mentlein R, Schaudig U, Pufe T, Recker K, Nolle B, et al. Differential expression of vascular endothelial growth factor implies the limbal origin of pterygia. Ophthalmology. 2005;112(6):1023-30.

6. Mauro J, Foster CS. Pterygia: pathogenesis and the role of subconjunctival bevacizumab in treatment. Semin Ophthalmol. 2009;24(3):130-4.

7. Ronald Pitts Crick PTK. A Textbook of Clinical Ophthalmology (A Practical Guide to Disorders of the Eyes and Their Management). 3rd ed: World Scientific; 2003.

8. Jaworski CJ, Aryankalayil-John M, Campos MM, Fariss RN, Rowsey J, Agarwalla N, et al. Expression analysis of human pterygium shows a predominance of conjunctival and limbal markers and genes associated with cell migration. Mol Vis. 2009;15:2421-34.

9. Toker E, Eraslan M. Recurrence After Primary Pterygium Excision: Amniotic Membrane Transplantation with Fibrin Glue Versus Conjunctival Autograft with Fibrin Glue. Curr Eye Res.41(1):1-8.

10. Hejtmancik JF, Shiels A. Overview of the Lens. Prog Mol Biol Transl Sci.134:119-27.

11. William M.Hart J. Adler's Physiology of the eye. 9th ed: George S.Stamathis; 1992.

12. F.Steinert R. Cataract Surgery. 3rd ed: Saunders Elsevier; 2010.

13. Steinert RF. Cataract Surgery. 3rd ed: Saunders Elsevier; 2010.

14. Vereb Z, Lumi X, Andjelic S, Globocnik-Petrovic M, Urbancic M, Hawlina M, et al. Functional and molecular characterization of ex vivo cultured epiretinal membrane cells from human proliferative diabetic retinopathy. BioMed research international. 2013;2013:492376.

15. Yamanaka O, Liu CY, Kao WW. Fibrosis in the anterior segments of the eye. Endocrine, metabolic \& immune disorders drug targets. 2010;10(4):331-5.

16. Chui J, Di Girolamo N, Wakefield D, Coroneo MT. The pathogenesis of pterygium: current concepts and their therapeutic implications. The ocular surface. 2008;6(1):24-43.

17. Bradley JC, Yang W, Bradley RH, Reid TW, Schwab IR. The science of pterygia. The British journal of ophthalmology. 2010;94(7):815-20.

18. Coroneo MT, Di Girolamo N, Wakefield D. The pathogenesis of pterygia. Current opinion in ophthalmology. 1999;10(4):282-8.

19. Saw SM, Tan D. Pterygium: prevalence, demography and risk factors. Ophthalmic epidemiology. 1999;6(3):219-28.

20. Hill JC, Maske R. Pathogenesis of pterygium. Eye. 1989;3 ( Pt 2):218-26.

21. Merjava S, Neuwirth A, Mandys V, Jirsova K. Cytokeratins 8 and 18 in adult human corneal endothelium. Experimental eye research. 2009;89(3):426-31.

22. Kasper M, Stosiek P, Lane B. Cytokeratin and vimentin heterogeneity in human cornea. Acta histochemica. 1992;93(2):371-81.

23. Albert R, Vereb Z, Csomos K, Moe MC, Johnsen EO, Olstad OK, et al. Cultivation and characterization of cornea limbal epithelial stem cells on lens capsule in animal materialfree medium. PloS one. 2012;7(10):e47187. 
24. Szabo DJ, Noer A, Nagymihaly R, Josifovska N, Andjelic S, Vereb Z, et al. LongTerm Cultures of Human Cornea Limbal Explants Form 3D Structures Ex Vivo - Implications for Tissue Engineering and Clinical Applications. PloS one. 2015;10(11):e0143053.

25. Liang K, Jiang Z, Ding BQ, Cheng P, Huang DK, Tao LM. Expression of cell proliferation and apoptosis biomarkers in pterygia and normal conjunctiva. Mol Vis. 2011;17:1687-93.

26. Reszec J, Kanczuga-Koda L, Sulkowska M, Koda M, Cylwik J, Barwijuk-Machala M, et al. An evaluation of Ki-67 and PCNA expression in conjunctival and eyelid tumours. Folia morphologica. 2004;63(1):95-8.

27. Strasser GA, Kaminker JS, Tessier-Lavigne M. Microarray analysis of retinal endothelial tip cells identifies CXCR4 as a mediator of tip cell morphology and branching. Blood. 2010;115(24):5102-10.

28. Abu El-Asrar AM, Struyf S, Opdenakker G, Van Damme J, Geboes K. Expression of stem cell factor/c-kit signaling pathway components in diabetic fibrovascular epiretinal membranes. Mol Vis. 2010;16:1098-107.

29. Castro-Munozledo F, Meza-Aguilar DG, Dominguez-Castillo R, HernandezZequinely V, Sanchez-Guzman E. Vimentin as a Marker of Early Differentiating, Highly Motile Corneal Epithelial Cells. Journal of cellular physiology. 2017;232(4):818-30.

30. Robertson DM, Ho SI, Cavanagh HD. C-terminal cleavage of DeltaNp63alpha is associated with TSA-induced apoptosis in immortalized corneal epithelial cells. Investigative ophthalmology \& visual science. 2010;51(8):3977-85.

31. Hsueh YJ, Kuo PC, Chen JK. Transcriptional regulators of the DeltaNp63: their role in limbal epithelial cell proliferation. Journal of cellular physiology. 2013;228(3):536-46.

32. Kormanovski A, Parra F, Jarillo-Luna A, Lara-Padilla E, Pacheco-Yepez J, CamposRodriguez R. Oxidant/antioxidant state in tissue of prymary and recurrent pterygium. BMC ophthalmology. 2014;14:149.

33. Maxia C, Perra MT, Demurtas P, Minerba L, Murtas D, Piras F, et al. Expression of survivin protein in pterygium and relationship with oxidative DNA damage. Journal of cellular and molecular medicine. 2008;12(6A):2372-80.

34. Perra MT, Maxia C, Corbu A, Minerba L, Demurtas P, Colombari R, et al. Oxidative stress in pterygium: relationship between p53 and 8-hydroxydeoxyguanosine. Mol Vis. 2006;12:1136-42.

35. Pagoulatos D, Pharmakakis N, Lakoumentas J, Assimakopoulou M. Etaypoxiainducible factor-1alpha, von Hippel-Lindau protein, and heat shock protein expression in ophthalmic pterygium and normal conjunctiva. Mol Vis. 2014;20:441-57.

36. Chui J, Coroneo MT, Tat LT, Crouch R, Wakefield D, Di Girolamo N. Ophthalmic pterygium: a stem cell disorder with premalignant features. The American journal of pathology. 2011;178(2):817-27.

37. Di Girolamo N, Chui J, Coroneo MT, Wakefield D. Pathogenesis of pterygia: role of cytokines, growth factors, and matrix metalloproteinases. Prog Retin Eye Res. 2004;23(2):195-228.

38. Poon MW, He J, Fang X, Zhang Z, Wang W, Wang J, et al. Human Ocular Epithelial Cells Endogenously Expressing SOX2 and OCT4 Yield High Efficiency of Pluripotency Reprogramming. PloS one. 2015;10(7):e0131288.

39. Morita M, Fujita N, Takahashi A, Nam ER, Yui S, Chung CS, et al. Evaluation of ABCG2 and p63 expression in canine cornea and cultivated corneal epithelial cells. Vet Ophthalmol. 2015;18(1):59-68.

40. Bhattacharya S, Das A, Mallya K, Ahmad I. Maintenance of retinal stem cells by Abcg2 is regulated by notch signaling. J Cell Sci. 2007;120(Pt 15):2652-62. 
41. Anguria P, Kitinya J, Ntuli S, Carmichael T. The role of heredity in pterygium development. International journal of ophthalmology. 2014;7(3):563-73.

42. Aspiotis M, Tsanou E, Gorezis S, Ioachim E, Skyrlas A, Stefaniotou M, et al. Angiogenesis in pterygium: study of microvessel density, vascular endothelial growth factor, and thrombospondin-1. Eye. 2007;21(8):1095-101.

43. Di Girolamo N, Kumar RK, Coroneo MT, Wakefield D. UVB-mediated induction of interleukin- 6 and -8 in pterygia and cultured human pterygium epithelial cells. Investigative ophthalmology \& visual science. 2002;43(11):3430-7.

44. Frucht-Pery J, Siganos CS, Ilsar M. Intraoperative application of topical mitomycin C for pterygium surgery. Ophthalmology. 1996;103(4):674-7.

45. Rubinfeld RS, Pfister RR, Stein RM, Foster CS, Martin NF, Stoleru S, et al. Serious complications of topical mitomycin-C after pterygium surgery. Ophthalmology. 1992;99(11):1647-54.

46. Rubinfeld RS, Stein RM. Topical mitomycin-C for pterygia: is single application appropriate? Ophthalmic surgery and lasers. 1997;28(8):662-9.

47. Chan CM, Liu YP, Tan DT. Ocular surface changes in pterygium. Cornea. 2002;21(1):38-42.

48. Leonard BC, Yanez-Soto B, Raghunathan VK, Abbott NL, Murphy CJ. Species variation and spatial differences in mucin expression from corneal epithelial cells. Experimental eye research. 2016;152:43-8.

49. Ablamowicz AF, Nichols JJ. Ocular Surface Membrane-Associated Mucins. The ocular surface. 2016;14(3):331-41.

50. Liu NP, Roberts WL, Hale LP, Levesque MC, Patel DD, Lu CL, et al. Expression of CD44 and variant isoforms in cultured human retinal pigment epithelial cells. Investigative ophthalmology \& visual science. 1997;38(10):2027-37.

51. Zhang J, Zhang M, Li X, Zheng T, Mu G, Liu W, et al. Correlation of vascular endothelial growth factor and CD105-microvascular density in primary pterygium. J Huazhong Univ Sci Technolog Med Sci. 2011;31(4):560-4.

52. Ye J, Song YS, Kang SH, Yao K, Kim JC. Involvement of bone marrow-derived stem and progenitor cells in the pathogenesis of pterygium. Eye. 2004;18(8):839-43.

53. Churchill GC, Atkinson MM, Louis CF. Mechanical stimulation initiates cell-to-cell calcium signaling in ovine lens epithelial cells. J Cell Sci. 1996;109 ( Pt 2):355-65.

54. Churchill GC, Lurtz MM, Louis $\mathrm{CF}$. $\mathrm{Ca}(2+)$ regulation of gap junctional coupling in lens epithelial cells. American journal of physiology Cell physiology. 2001;281(3):C972-81.

55. Yawata K, Nagata M, Narita A, Kawai Y. Effects of long-term acidification of extracellular $\mathrm{pH}$ on ATP-induced calcium mobilization in rabbit lens epithelial cells. The Japanese journal of physiology. 2001;51(1):81-7.

56. Andjelic S, Zupancic G, Perovsek D, Hawlina M. Human anterior lens capsule epithelial cells contraction. Acta ophthalmologica. 2011;89(8):e645-53.

57. Osborne-Hereford AV, Rogers SW, Gahring LC. Neuronal nicotinic alpha7 receptors modulate inflammatory cytokine production in the skin following ultraviolet radiation. Journal of neuroimmunology. 2008;193(1-2):130-9.

58. Pladzyk A, Reddy AB, Yadav UC, Tammali R, Ramana KV, Srivastava SK. Inhibition of aldose reductase prevents lipopolysaccharide-induced inflammatory response in human lens epithelial cells. Investigative ophthalmology \& visual science. 2006;47(12):5395403.

59. Blatteis CM, Li S, Li Z, Feleder C, Perlik V. Cytokines, PGE2 and endotoxic fever: a re-assessment. Prostaglandins \& other lipid mediators. 2005;76(1-4):1-18. 
60. De Angelo J. Nitric oxide scavengers in the treatment of shock associated with systemic inflammatory response syndrome. Expert opinion on pharmacotherapy. 1999;1(1):19-29.

61. Wu A, Hinds CJ, Thiemermann C. High-density lipoproteins in sepsis and septic shock: metabolism, actions, and therapeutic applications. Shock. 2004;21(3):210-21.

62. Muller JM, Ziegler-Heitbrock HW, Baeuerle PA. Nuclear factor kappa B, a mediator of lipopolysaccharide effects. Immunobiology. 1993;187(3-5):233-56.

63. Penland RL, Boniuk M, Wilhelmus KR. Vibrio ocular infections on the U.S. Gulf Coast. Cornea. 2000;19(1):26-9.

64. Hazlett LD. Corneal response to Pseudomonas aeruginosa infection. Prog Retin Eye Res. 2004;23(1):1-30.

65. Sack RA, Nunes I, Beaton A, Morris C. Host-defense mechanism of the ocular surfaces. Bioscience reports. 2001;21(4):463-80.

66. Palexas GN, Sussman G, Welsh NH. Ocular and systemic determination of IL-1 beta and tumour necrosis factor in a patient with ocular inflammation. Scandinavian journal of immunology Supplement. 1992;11:173-5.

67. Nishi K, Nishi O, Omoto Y. [The synthesis of cytokines by human lens epithelial cells--interleukin 1 (IL-1), tumor necrosis factor (TNF) interleukin 6 (IL-6), and epidermal growth factor (EGF)]. Nippon Ganka Gakkai zasshi. 1992;96(6):715-20.

68. Sachdev NH, Di Girolamo N, Nolan TM, McCluskey PJ, Wakefield D, Coroneo MT. Matrix metalloproteinases and tissue inhibitors of matrix metalloproteinases in the human lens: implications for cortical cataract formation. Investigative ophthalmology \& visual science. 2004;45(11):4075-82.

69. Prada J, Ngo-Tu T, Baatz H, Hartmann C, Pleyer U. Detection of tumor necrosis factor alpha and interleukin 1 alpha gene expression in human lens epithelial cells. Journal of cataract and refractive surgery. 2000;26(1):114-7.

70. Ramana KV, Friedrich B, Bhatnagar A, Srivastava SK. Aldose reductase mediates cytotoxic signals of hyperglycemia and TNF-alpha in human lens epithelial cells. FASEB journal : official publication of the Federation of American Societies for Experimental Biology. 2003;17(2):315-7.

71. Collins T, Cybulsky MI. NF-kappaB: pivotal mediator or innocent bystander in atherogenesis? The Journal of clinical investigation. 2001;107(3):255-64.

72. Nishi O, Nishi K, Wada K, Ohmoto Y. Expression of transforming growth factor (TGF)-alpha, TGF-beta(2) and interleukin 8 messenger RNA in postsurgical and cultured lens epithelial cells obtained from patients with senile cataracts. Graefe's archive for clinical and experimental ophthalmology $=$ Albrecht von Graefes Archiv fur klinische und experimentelle Ophthalmologie. 1999;237(10):806-11.

73. Nishi O, Nishi K, Ohmoto Y. Synthesis of interleukin-1, interleukin-6, and basic fibroblast growth factor by human cataract lens epithelial cells. Journal of cataract and refractive surgery. 1996;22 Suppl 1:852-8.

74. Harocopos GJ, Alvares KM, Kolker AE, Beebe DC. Human age-related cataract and lens epithelial cell death. Investigative ophthalmology \& visual science. 1998;39(13):2696706.

75. Limb GA, Chignell AH, Green W, LeRoy F, Dumonde DC. Distribution of TNF alpha and its reactive vascular adhesion molecules in fibrovascular membranes of proliferative diabetic retinopathy. The British journal of ophthalmology. 1996;80(2):168-73.

76. Gustavsson C, Agardh E, Bengtsson B, Agardh CD. TNF-alpha is an independent serum marker for proliferative retinopathy in type 1 diabetic patients. Journal of diabetes and its complications. 2008;22(5):309-16. 
77. Takeuchi M, Sato T, Tanaka A, Muraoka T, Taguchi M, Sakurai Y, et al. Elevated Levels of Cytokines Associated with Th2 and Th17 Cells in Vitreous Fluid of Proliferative Diabetic Retinopathy Patients. PloS one. 2015;10(9):e0137358.

78. Koskela UE, Kuusisto SM, Nissinen AE, Savolainen MJ, Liinamaa MJ. High vitreous concentration of IL-6 and IL-8, but not of adhesion molecules in relation to plasma concentrations in proliferative diabetic retinopathy. Ophthalmic research. 2013;49(2):108-14.

79. Zhou J, Wang S, Xia X. Role of intravitreal inflammatory cytokines and angiogenic factors in proliferative diabetic retinopathy. Curr Eye Res. 2012;37(5):416-20.

80. Kohl J. Anaphylatoxins and infectious and non-infectious inflammatory diseases. Molecular immunology. 2001;38(2-3):175-87.

81. Cortright DN, Meade R, Waters SM, Chenard BL, Krause JE. C5a, but not C3a, increases VEGF secretion in ARPE-19 human retinal pigment epithelial cells. Curr Eye Res. 2009;34(1):57-61.

82. Ambati J, Anand A, Fernandez S, Sakurai E, Lynn BC, Kuziel WA, et al. An animal model of age-related macular degeneration in senescent Ccl-2- or Ccr-2-deficient mice. Nature medicine. 2003;9(11):1390-7.

83. Fukuoka Y, Strainic M, Medof ME. Differential cytokine expression of human retinal pigment epithelial cells in response to stimulation by C5a. Clinical and experimental immunology. 2003;131(2):248-53.

84. Muramatsu D, Wakabayashi Y, Usui Y, Okunuki Y, Kezuka T, Goto H. Correlation of complement fragment C5a with inflammatory cytokines in the vitreous of patients with proliferative diabetic retinopathy. Graefe's archive for clinical and experimental ophthalmology $=$ Albrecht von Graefes Archiv fur klinische und experimentelle Ophthalmologie. 2013;251(1):15-7.

85. van Beijnum JR, Buurman WA, Griffioen AW. Convergence and amplification of tolllike receptor (TLR) and receptor for advanced glycation end products (RAGE) signaling pathways via high mobility group B1 (HMGB1). Angiogenesis. 2008;11(1):91-9.

86. Fiuza C, Bustin M, Talwar S, Tropea M, Gerstenberger E, Shelhamer JH, et al. Inflammation-promoting activity of HMGB1 on human microvascular endothelial cells. Blood. 2003;101(7):2652-60.

87. Treutiger CJ, Mullins GE, Johansson AS, Rouhiainen A, Rauvala HM, ErlandssonHarris $\mathrm{H}$, et al. High mobility group 1 B-box mediates activation of human endothelium. Journal of internal medicine. 2003;254(4):375-85.

88. Luan ZG, Zhang H, Yang PT, Ma XC, Zhang C, Guo RX. HMGB1 activates nuclear factor-kappaB signaling by RAGE and increases the production of TNF-alpha in human umbilical vein endothelial cells. Immunobiology. 2010;215(12):956-62.

89. Mitola S, Belleri M, Urbinati C, Coltrini D, Sparatore B, Pedrazzi M, et al. Cutting edge: extracellular high mobility group box-1 protein is a proangiogenic cytokine. Journal of immunology. 2006;176(1):12-5.

90. Schlueter C, Weber H, Meyer B, Rogalla P, Roser K, Hauke S, et al. Angiogenetic signaling through hypoxia: HMGB1: an angiogenetic switch molecule. The American journal of pathology. 2005;166(4):1259-63.

91. Chavakis E, Hain A, Vinci M, Carmona G, Bianchi ME, Vajkoczy P, et al. Highmobility group box 1 activates integrin-dependent homing of endothelial progenitor cells. Circulation research. 2007;100(2):204-12.

92. van Beijnum JR, Dings RP, van der Linden E, Zwaans BM, Ramaekers FC, Mayo $\mathrm{KH}$, et al. Gene expression of tumor angiogenesis dissected: specific targeting of colon cancer angiogenic vasculature. Blood. 2006;108(7):2339-48. 
93. El-Asrar AM, Nawaz MI, Kangave D, Geboes K, Ola MS, Ahmad S, et al. Highmobility group box-1 and biomarkers of inflammation in the vitreous from patients with proliferative diabetic retinopathy. Mol Vis. 2011;17:1829-38.

94. Xu Y, Cheng Q, Yang B, Yu S, Xu F, Lu L, et al. Increased sCD200 Levels in Vitreous of Patients With Proliferative Diabetic Retinopathy and Its Correlation With VEGF and Proinflammatory Cytokines. Investigative ophthalmology \& visual science. 2015;56(11):6565-72. 